\title{
Human Cytomegalovirus Latency and Reactivation in Allogeneic Hematopoietic Stem Cell Transplant Recipients
}

\author{
Lauren Stern', Barbara Withers ${ }^{2 \dagger}$, Selmir Avdic $3,4 t$, David Gottlieb ${ }^{3,4,5 t}$, \\ Allison Abendroth ${ }^{1+}$, Emily Blyth ${ }^{3,4,5+}$ and Barry Slobedman ${ }^{1 * \dagger}$
}

1 Discipline of Infectious Diseases and Immunology, Sydney Medical School, Charles Perkins Centre, University of Sydney, Sydney, NSW, Australia, ${ }^{2}$ Department of Haematology, St Vincent's Hospital, Darlinghurst, NSW, Australia, ${ }^{3}$ Westmead Institute of Medical Research, University of Sydney, Sydney, NSW, Australia, ${ }^{4}$ Sydney Cellular Therapies Laboratory, Westmead, NSW, Australia, ${ }^{5}$ Blood and Marrow Transplant Unit, Westmead Hospital, Sydney, NSW, Australia

OPEN ACCESS

Edited by:

Benedikt B. Kaufer, Freie Universität Berlin, Germany

Reviewed by: Mark R. Wills, University of Cambridge, United Kingdom Sebastian Voigt Charité Medical University of Berlin,

Germany

*Correspondence:

Barry Slobedman barry.slobedman@sydney.edu.au

${ }^{\dagger}$ These authors have contributed equally to this work

Specialty section: This article was submitted to Virology, a section of the journal Frontiers in Microbiology

Received: 31 March 2019 Accepted: 09 May 2019 Published: 28 May 2019

Citation:

Stern L, Withers B, Avdic S, Gottlieb D, Abendroth A, Blyth E and

Slobedman B (2019) Human

Cytomegalovirus Latency and Reactivation in Allogeneic Hematopoietic Stem Cell Transplant Recipients. Front. Microbiol. 10:1186.

doi: 10.3389/fmicb.2019.01186
Human cytomegalovirus (HCMV) reactivation is a major infectious cause of morbidity and mortality after allogeneic hematopoietic stem cell transplantation (HSCT). HCMV is a ubiquitous beta-herpesvirus which asymptomatically infects immunocompetent individuals but establishes lifelong latency, with the potential to reactivate to a lifethreatening productive infection when the host immune system is suppressed or compromised. Opportunistic HCMV reactivation is the most common viral complication following engraftment after HSCT and is associated with a marked increase in nonrelapse mortality, which appears to be linked to complex effects on post-transplant immune recovery. This minireview explores the cellular sites of HCMV latency and reactivation in HSCT recipients and provides an overview of the risk factors for HCMV reactivation post-HSCT. The impact of HCMV in shaping post-transplant immune reconstitution and its relationship with patient outcomes such as relapse and graft-versus-host disease will be discussed. Finally, we survey current and emerging strategies to prevent and control HCMV reactivation in HSCT recipients, with recent developments including adoptive $T$ cell therapies to accelerate HCMV-specific $T$ cell reconstitution and new anti-HCMV drug therapy for HCMV reactivation after HSCT.

Keywords: human cytomegalovirus, HCMV, CMV, latency, reactivation, hematopoietic stem cell transplant, HSCT

\section{INTRODUCTION}

Human cytomegalovirus (HCMV) is a beta-herpesvirus carried by a majority of the global population (Cannon et al., 2010; Zuhair et al., 2019). The seroprevalence of HCMV increases with age and has an estimated global mean of $83 \%$ (Zuhair et al., 2019). While primary infection is usually asymptomatic in immunocompetent individuals, the virus establishes a lifelong latent infection that is never eliminated by the host immune system. Intermittent subclinical viral reactivation events are thought to be controlled by effective immune surveillance and may drive the high frequencies of HCMV-specific T-cells found in the peripheral blood of healthy seropositive individuals (Sester et al., 2002; Sylwester et al., 2005). By contrast, reactivation from latency is responsible for significant morbidity and mortality in immunocompromised and immunosuppressed populations, 
including solid-organ transplant and allogeneic hematopoietic stem cell transplant (HSCT) recipients, HIV/AIDS patients and the developing fetus.

HCMV reactivation is the major viral infectious complication after allogeneic HSCT and is associated with an increased risk of non-relapse mortality (Takenaka et al., 2015; Green et al., 2016; Teira et al., 2016), which is not principally attributable to direct HCMV disease (Green et al., 2016). Uncontrolled HCMV replication following reactivation can lead to life-threatening end-organ disease, commonly manifesting as pneumonia and gastrointestinal disease, and less frequently as retinitis, hepatitis and encephalitis. Reactivation may also indirectly contribute to detrimental patient outcomes through antiviral drug toxicities and complex impacts on post-transplant immune reconstitution, including links with graft-versus-host disease (GvHD) (Cantoni et al., 2010) and microbial superinfections (Nichols et al., 2002; Yong et al., 2017a). There is no licensed HCMV vaccine and current antiviral agents are limited by their toxic side-effects and the risk of antiviral drug resistance.

The cellular sites and mechanisms associated with HCMV latency and reactivation are incompletely understood, in part due to the high human-specificity of HCMV which precludes the use of animal models to directly study HCMV infection. Clinical evidence indicates that the risk of reactivation postHSCT is strongly connected to the pre-transplant HCMV serostatus of the donor and recipient (Boeckh and Nichols, 2004; George et al., 2010) and the pace of post-transplant HCMVspecific T-cell recovery. However, the lack of well-validated biomarkers for reactivation makes it challenging to predict the incidence and outcome of infection in individual patients, and greater knowledge of the influence of HCMV on post-transplant immune reconstitution is required.

\section{HCMV REACTIVATION IN ALLOGENEIC HEMATOPOIETIC STEM CELL TRANSPLANTATION (HSCT)}

Allogeneic HSCT is the only curative option for many hematological malignancies and diseases (Copelan, 2006). GvHD, opportunistic infections and relapse are the leading causes of mortality in the first 2 years post-transplant (Gratwohl et al., 2005; D'Souza and Fretham, 2018). The reactivation of latent double-stranded DNA viruses is common in the early post-engraftment period (Hill et al., 2017) and HCMV reactivation is the most frequent opportunistic viral infection after HSCT. Virological surveillance for HCMV replication is routinely performed in the first 100 days post-transplant through quantitative PCR monitoring for HCMV genomes in blood plasma (Emery et al., 2000), with HCMV DNAemia being an independent risk factor for disease (Zaia et al., 1997) and nonrelapse mortality (Hiwarkar et al., 2013; Green et al., 2016; Ramanathan et al., 2016; Teira et al., 2016).

Reactivation develops in over $60 \%$ of HCMV seropositive recipients $(\mathrm{R}+)$, and in approximately $10 \%$ of seronegative recipients $(\mathrm{R}-)$ transplanted from seropositive donors $(\mathrm{D}+)$ (George et al., 2010). In $\mathrm{R}+/ \mathrm{D}+$ patients, reactivation may derive from endogenous latent $\mathrm{HCMV}$ in the seropositive recipient (Winston et al., 1985; Kawasaki et al., 1999) and/or from latently infected cells transferred within the seropositive donor stem cell allograft. Recipient seropositivity alone is an adverse prognostic factor for overall survival (Broers et al., 2000; Craddock et al., 2001). Seropositive recipients who receive grafts from $\mathrm{HCMV}$-naïve donors $(\mathrm{R}+/ \mathrm{D}-)$ experience the highest incidence of HCMV reactivation and disease (Ljungman et al., 2006; Webb et al., 2018), a likely consequence of delayed HCMVspecific immune recovery owing to the lack of pre-existing HCMV-specific memory lymphocytes in the graft (Cwynarski et al., 2001; Zhou et al., 2009). As the recipient's existing cellular immune system is eradicated by transplant conditioning regimens, $\mathrm{R}+/ \mathrm{D}-$ patients rely on de novo $\mathrm{T}$-cell reconstitution via the thymus from donated pluripotent hematopoietic stem cells to generate a primary T-cell response to HCMV reactivation. By contrast, HCMV-specific memory T-cells contained in D+ grafts can undergo more rapid antigen-driven expansion within the recipient in the early post-transplant period and contribute to early control of reactivation (Cwynarski et al., 2001; Gandhi et al., 2003; Scheinberg et al., 2009). For a seropositive recipient, the choice of a seropositive over seronegative donor offers a survival advantage in the setting of myeloablative unrelated donor transplantation, but the effect on survival with matched sibling donors is less strong (Ljungman et al., 2003, 2014). Nonetheless, due to the high incidence of HCMV-related complications in $\mathrm{R}+/ \mathrm{D}-$ patients, where possible, attempts are made to match serostatus in donors and recipients.

Advances in transplant and antiviral treatment practices over the last 25 years have reduced the incidence of HCMV disease to $\sim 10 \%$ in the first year post-transplant (Boeckh and Ljungman, 2009; Green et al., 2016). However, the use of prophylactic or preemptive antiviral therapy delays HCMV-specific T-cell recovery (Li et al., 1994) and has led to increasing rates of late HCMV reactivation and disease (Einsele et al., 2000). Additionally, HCMV pneumonia remains associated with high (up to 70\%) mortality (Erard et al., 2015). Gastrointestinal HCMV disease often develops without detection of HCMV DNAemia (Cho et al., 2013; Gabanti et al., 2015) and can be difficult to distinguish from gastrointestinal GvHD, often occurring in the same patients (Cho et al., 2013; Bhutani et al., 2015).

\section{CELLULAR SITES OF HCMV LATENCY AND REACTIVATION}

The transition from viral latency to reactivation underpins the pathogenesis of HCMV in HSCT. HCMV latency is characterized by maintenance of the viral genome as an intranuclear episome (Bolovan-Fritts et al., 1999) without replication, but with the potential to reactivate to a productive infection. A wide range of cell types support productive infection (Ibanez et al., 1991; Sinzger et al., 2008), but latency appears to be restricted to primitive bone-marrow-resident $\mathrm{CD} 34^{+}$cells and $\mathrm{CD}_{3}{ }^{+}$ myeloid progenitor cells (Mendelson et al., 1996; Hahn et al., 1998; Reeves et al., 2005b), which retain the latent viral genome as they differentiate into peripheral blood $\mathrm{CD} 14^{+}$monocytes and 
myeloid dendritic cells (mDCs) (Taylor-Wiedeman et al., 1991, 1994; Hahn et al., 1998; Khaiboullina et al., 2004; Reeves et al., 2005b). A recent study found that CD14 ${ }^{+}$monocytes expressing the surface marker B7-H4 were a predominant site of latency in peripheral blood of healthy donors (Zhu et al., 2018). It may be that HCMV preferentially infects early myeloid progenitors or promotes the differentiation of infected pluripotent CD $34^{+}$cells to myeloid-lineage subsets that support latency (Zhu et al., 2018).

Latently infected cells contain HCMV DNA (Minton et al., 1994) but do not support infectious virus production. The terminal differentiation to mature $\mathrm{mDCs}$ and macrophages is accompanied by chromatin remodeling of the HCMV major immediate-early promoter (Reeves et al., 2005a,b), which facilitates reactivation of the lytic gene cascade and the production of infectious virus (Taylor-Wiedeman et al., 1994; Reeves et al., 2005b; Reeves and Sinclair, 2013; Poole et al., 2015). Allogeneic stimulation (Soderberg-Naucler et al., 1997) and pro-inflammatory cytokines such as IFN- $\gamma$, TNF, and IL-6 are implicated in driving myeloid cell maturation and reactivation (Fietze et al., 1994; Söderberg-Nauclér et al., 2001; Hargett and Shenk, 2010; Reeves and Compton, 2011; Huang et al., 2012; Reeves and Sinclair, 2013; Forte et al., 2018).

Latently infected cells are present at very low frequencies (0.004-0.01\% of mononuclear cells) in GCSF-mobilized peripheral blood or bone-marrow from healthy seropositive donors (Slobedman and Mocarski, 1999), but underlie the capacity for iatrogenic transmission of latent HCMV through $\mathrm{D}+$ HSCT allografts. Additionally, the high risk of reactivation in $\mathrm{R}+/ \mathrm{D}-$ patients suggests that pre-transplant conditioning regimens incompletely eradicate latent HCMV reservoirs in the recipient (Wills et al., 2015). It also remains possible there are additional sites of HCMV latency, with conflicting evidence regarding possible latency in aortic endothelial cells (Fish et al., 1998; Pampou et al., 2000; Reeves et al., 2004). Whether HCMV establishes a low-level productive infection in bone-marrow stromal cells (Taichman et al., 1997; Smirnov et al., 2007; Soland et al., 2014) or in a self-renewing CD34 ${ }^{+}$cell subset (Goodrum et al., 2004) also remains unclear, yet HCMV DNA has been detected in diverse tissue sites (Hendrix et al., 1997; Chen and Hudnall, 2006; Gordon et al., 2017) and recent RNA-seq uncovered HCMV transcripts at multiple locations, including the ovaries, blood, adipose tissue, and lung (Shnayder et al., 2018). The specific cell types harboring HCMV in these studies and whether they represent productive, abortive, or latent infection is unknown. The widespread prevalence of HCMV within asymptomatic individuals nonetheless highlights the importance of host immune control in preventing unchecked HCMV replication leading to life-threatening disease.

\section{RISK FACTORS FOR HCMV REACTIVATION AFTER HSCT}

In addition to recipient and donor HCMV serostatus, independent risk factors for reactivation include increasing recipient age (Tong et al., 2013; Takenaka et al., 2015), use of unrelated or HLA-mismatched donors (Qayed et al., 2014;
Takenaka et al., 2015), T-cell depletion (Walker et al., 2007; Yoon et al., 2009), GvHD (Walker et al., 2007; George et al., 2010; Qayed et al., 2014; Cohen et al., 2015), and high-dose corticosteroids for GvHD (Yanada et al., 2003; Tong et al., 2013; Melendez-Munoz et al., 2019). T-cell depletion and prolonged steroid therapy mitigate GvHD but delay antiviral T-cell reconstitution (Aubert et al., 2001; Craddock et al., 2001; Wagner et al., 2005; Lilleri et al., 2009; Tormo et al., 2011). A high incidence of HCMV reactivation is also observed after T-cell replete haploidentical HSCT with post-transplant cyclophosphamide (Di Stasi et al., 2014; Crocchiolo et al., 2015; Goldsmith et al., 2016; Slade et al., 2017).

The reconstitution kinetics of HCMV-specific T-cells postHSCT have a close relationship with the risk and prognosis of reactivation (Lilleri et al., 2006; Gratama et al., 2010; Espigado et al., 2014). HCMV-specific $\mathrm{CD}^{+}{ }^{+}$and $\mathrm{CD}^{+}$T-cells expand with reactivation and are likely both required for control and/or protection (Foster et al., 2002; Sacre et al., 2008; Widmann et al., 2008; Pourgheysari et al., 2009; Lilleri et al., 2012; Gabanti et al., 2015; Raeiszadeh et al., 2015; Ciaurriz et al., 2017). Quantitative thresholds of $\mathrm{CD}^{+}$and $\mathrm{CD} 4{ }^{+} \mathrm{HCMV}$-specific T-cells associated with protection from, or control of, reactivation or disease post-HSCT have been defined using HLA tetramers or ex vivo viral stimulation assays (Aubert et al., 2001; Cwynarski et al., 2001; Gratama et al., 2001, 2010; Lilleri et al., 2008; MoinsTeisserenc et al., 2008; Borchers et al., 2011, 2012; Tormo et al., 2011; Lilleri et al., 2012; Liu et al., 2016). Threshold numbers have not been well-validated for routine clinical use and are less informative of protection from reactivation and disease in patients under steroid therapy or with prior GvHD (Lilleri et al., 2012; Gabanti et al., 2015).

Control of reactivation may depend more heavily on the functional recovery of HCMV-specific T-cell immunity (Quinnan et al., 1982; Reusser et al., 1991; Ozdemir et al., 2002; Nakamura et al., 2004; Gratama et al., 2008; Zhou et al., 2009; Tormo et al., 2010; Krol et al., 2011; Tey et al., 2013; Espigado et al., 2014; Ciaurriz et al., 2017). Polyfunctional HCMV-specific T-cell responses post-HSCT are associated with lower viral loads, protection from subsequent episodes of reactivation and lower antiviral therapy requirements (Zhou et al., 2009; Munoz-Cobo et al., 2012; Gimenez et al., 2015; Pelak et al., 2017). Delayed or undetectable HCMV-specific cytotoxic T-cell responses are prominent risk factors for HCMV disease (Reusser et al., 1991; Gratama et al., 2001; Ganepola et al., 2007). Camargo et al. (2019) recently described a composite biomarker comprising a protective (IL- $2+$ IFN- $\gamma+$ TNF- $\alpha+$ MIP$1 \beta+$ ) and non-protective (IL-2-IFN- $\gamma+$ TNF- $\alpha-\mathrm{MIP}-1 \beta+) \mathrm{CD}^{+}$ T-cell cytokine signature in response to in vitro HCMV pp65 peptide stimulation that independently predicted the risk of clinically significant reactivation. Assessment of HCMV-specific immunity through measurement of whole blood ex vivo IFN$\gamma$ secretion responses to HCMV peptides has also emerged as a promising prognostic approach for HCMV reactivation postHSCT (Tey et al., 2013; Yong et al., 2017b). However, it is argued that the selective recovery of HCMV-specific T-cell immunity ahead of global T-cell reconstitution carries a higher risk of subsequent reactivation (Tey et al., 2014). 
The detection of reactivation prior to 100 days post-transplant (Boeckh et al., 2003; Kim et al., 2004; Liu et al., 2015), plasma viral load (Zaia et al., 1997), leukopenia (Jang et al., 2012), lymphopenia (Einsele et al., 1993), and GvHD (Boeckh et al., 2003; Ljungman et al., 2006; Green et al., 2012) represent additional risk factors for HCMV disease. Donor grafts with $\geq 5$ activating killer-cell immunoglobulin-like receptor (KIR) genes or with both KIR2DS2 and KIR2DS4 predict a lower risk of reactivation (Zaia et al., 2009), and the use of donors with multiple or additional activating KIRs is associated with a lower incidence of reactivation (Chen et al., 2006; Cook et al., 2006).

\section{IMPACT OF HCMV REACTIVATION ON POST-HSCT IMMUNE RECOVERY, RELAPSE AND GvHD}

The immune system crucially regulates the risk of HCMV reactivation and disease, but HCMV itself also has a profound influence in shaping immune profiles in healthy seropositive individuals (Chidrawar et al., 2009; Brodin et al., 2015; Patin et al., 2018) and HSCT patients (Itzykson et al., 2015; Lakshmikanth et al., 2017), although the functional implications of this immune modulation are not yet clear. In some HSCT recipients, reactivation might be an epiphenomenon of poor immune reconstitution, but it is also possible that the immunomodulatory effects of HCMV infection may contribute to poor posttransplant outcomes (Nichols et al., 2002). Indeed, while HCMV DNAemia-guided pre-emptive antiviral therapy has reduced the incidence of HCMV disease post-HSCT, the survival disadvantage associated with HCMV infection has not been eliminated (Broers et al., 2000; Schmidt-Hieber et al., 2013; Green et al., 2016). HCMV encodes a range of immunomodulatory gene products that are expressed during both productive infection and latency, including a homolog of the immunosuppressive cytokine IL-10 (Jenkins et al., 2004; McSharry et al., 2012; Avdic et al., 2014; Young et al., 2017). HCMV infection in HSCT recipients increases the risk of bacterial and fungal superinfections (Nichols et al., 2002; Yong et al., 2017a) and GvHD (Lonnqvist et al., 1984; Broers et al., 2000; Cantoni et al., 2010), which might be connected to complex impacts of HCMV reactivation and/or its treatment on post-transplant immune recovery.

\section{T Cell Reconstitution}

Reactivation stimulates the recovery of HCMV-specific T-cells after HSCT (see section "Risk Factors for HCMV Reactivation After HSCT”) (Hakki et al., 2003; Tormo et al., 2010; Ciaurriz et al., 2017), but is also accompanied by broader changes in the T-cell compartment. Patients with reactivation display accelerated $\mathrm{CD}^{+}$T-cell reconstitution in the first year posttransplant (Lugthart et al., 2014; Drylewicz et al., 2016), which is likely to be driven by clonal expansions of HCMV-specific effector-memory $\alpha \beta \mathrm{CD}^{+}$T-cells (Suessmuth et al., 2015; Link et al., 2016), leading to an inverted CD4:CD8 ratio. Deep sequencing of the TCR- $\beta$ repertoire at 1 year postHSCT uncovered a contraction in effector-memory CD8 ${ }^{+}$TCR diversity and holes in the underlying effector-memory $\mathrm{CD}^{+}$
T-cell repertoire in patients who had experienced reactivation (Suessmuth et al., 2015). The selective expansion of HCMVreactive $\mathrm{V} \delta 2^{\text {neg }} \gamma \delta \mathrm{T}$-cells (Knight et al., 2010; Scheper et al., 2013), and clonal ( $\mathrm{V} \gamma 9^{\text {neg }}$ and $\left.\mathrm{V} \delta 2^{\text {neg }}\right) \gamma \delta \mathrm{T}$-cell proliferations suggestive of adaptive responses (Ravens et al., 2017), are also observed following reactivation. Reactivation also triggers the expansion of large granular lymphocytes (Nann-Rütti et al., 2012). Lugthart et al. (2014) found the reconstitution of naïve and central memory T-cells up to 2 years post-transplant was not compromised by reactivation, but Suessmuth et al. (2015) observed lower numbers of naïve T-cells in the first year post-HSCT in patients with reactivation. Many of the immunological features associated with HCMV reactivation after HSCT, including oligoclonal expansions of terminally differentiated HCMV-specific T-cells, are also found with aging in seropositive individuals (Khan et al., 2002; Hadrup et al., 2006), although recently it was reported that these HCMVinduced clonal T-cell expansions may not compromise CD8 ${ }^{+}$ T-cell repertoire diversity in the elderly (Lindau et al., 2019). The prominent influence of HCMV seropositivity and reactivation in shaping global immune reconstitution signatures after HSCT is apparent (Itzykson et al., 2015), but the impact of reactivation on immune recovery beyond 2 years post-transplant is not wellcharacterized.

\section{NK Cell Reconstitution}

HCMV reactivation drives a rapid expansion of IFN- $\gamma$-producing $\mathrm{NKG}_{2} \mathrm{C}^{+} \mathrm{NK}$ cells (Foley et al., 2012b), which likely contribute to early control of reactivation (Kheav et al., 2014; Davis et al., 2015; Muccio et al., 2016). Expanded proportions of mature

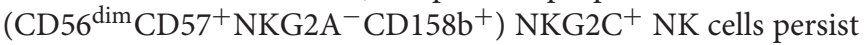
after viral clearance (Foley et al., 2012b) and memory-like expansions of $\mathrm{NKG}_{2} \mathrm{C}^{+} \mathrm{CD} 57^{+} \mathrm{NK}$ cells are also observed in $\mathrm{R}+/ \mathrm{D}+$ patients with subclinical HCMV infection (Foley et al., 2012a). Specific recognition by $\mathrm{NKG}^{+} \mathrm{C}^{+} \mathrm{NK}$ cells of HCMV UL40 peptides presented in the context of HLA-E was recently identified to be the mechanism that drives the expansion and differentiation of $\mathrm{NKG}_{2} \mathrm{C}^{+} \mathrm{NK}$ cells during HCMV infection (Hammer et al., 2018).

\section{Relapse}

An association between early HCMV reactivation and reduced myeloid leukemia relapse has been reported (Lonnqvist et al., 1986; Elmaagacli et al., 2011; Green et al., 2013; Ito et al., 2013; Takenaka et al., 2015; Peric et al., 2018). This putative protective effect might be mediated through the anti-leukemic activities of

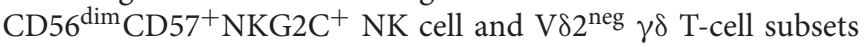
which expand with reactivation (Scheper et al., 2013; Cichocki et al., 2016), or via enhancement of donor alloimmune responses in the presence of infection and HCMV-specific CD8 ${ }^{+}$T-cells (Ogonek et al., 2017; Varanasi et al., 2019). However, the role of reactivation in protection from malignancy relapse postHSCT is controversial, as others have not found evidence of this association in patients with acute myeloid leukemia, chronic myeloid leukemia, acute lymphoid leukemia, lymphoma, or myelodysplastic syndrome (Nakamura et al., 2004; Green et al., 2013; Jeljeli et al., 2014; Mariotti et al., 2014; Takenaka et al., 2015; 
Teira et al., 2016; Ramanathan et al., 2016; Admiraal et al., 2017). Further studies are thus required to better define the patient subgroups and immunological features associated with possible relapse protection in HSCT patients with HCMV reactivation.

\section{Graft-Versus-Host Disease}

Graft-versus-host disease and its steroid therapy increase the risk of reactivation after HSCT (Miller et al., 1986; Yanada et al., 2003; Ljungman et al., 2006; George et al., 2012; Liu et al., 2015; Valadkhani et al., 2016). The alloimmune responses mediating GvHD impair thymopoiesis (Weinberg et al., 2001; Castermans et al., 2011) and delay HCMV-specific T-cell reconstitution, and high-dose steroids impair the recovery of HCMV-specific T-cells in a dose-dependent manner (Hakki et al., 2003; Widmann et al., 2008). Further, it has been speculated that the proinflammatory immune environment associated with GvHD may promote reactivation, as has been demonstrated following allogeneic stimulation of latently infected cells ex vivo (Soderberg-Naucler et al., 1997). Conversely, patients with reactivation more frequently develop GvHD (Lonnqvist et al., 1984; Janeczko et al., 2016) and the risk of extensive chronic GvHD was reduced with the use of HCMV DNAemia-guided pre-emptive antiviral therapy (Larsson et al., 2004). An increased risk of acute GvHD was observed during episodes of active HCMV replication after HSCT, supporting a bidirectional relationship between reactivation and GvHD (Cantoni et al., 2010). Further research is required to delineate the mechanisms underlying this phenomenon, but an inflammatory response to reactivation or the potential cross-reactivity of HCMV-specific T-cells with human alloantigens (Hall et al., 2017) might play a role.

\section{PREVENTION AND TREATMENT STRATEGIES}

Standard antiviral drugs for reactivation after HSCT are ganciclovir, valganciclovir and foscarnet. Prophylactic use is reserved for high-risk patients due to their significant toxic side effects. Ganciclovir causes neutropenia which increases the risk of bacterial and fungal superinfections (Goodrich et al., 1993; Boeckh et al., 1996; Broers et al., 2000; Einsele et al., 2000; Yanada et al., 2003), while foscarnet and cidofovir (used as a second- or third- line therapy) (Ljungman et al., 2008) are nephrotoxic (Ljungman et al., 2001; Reusser et al., 2002). Additional concerns relate to the development of antiviral drug resistance (Campos et al., 2016; Servais et al., 2016; Chemaly et al., 2018) and breakthrough reactivation or disease (Green et al., 2012). HCMV drug resistance has been reported in up to $14.5 \%$ of HSCT recipients receiving pre-emptive therapy (Shmueli et al., 2014). Prolonged antiviral exposure (Boeckh and Ljungman, 2009), suboptimal prophylactic dosing (Lischka et al., 2016), corticosteroid therapy (Frietsch et al., 2019) and delayed immune reconstitution foster the selection of drug resistant HCMV mutants. Mutations in the HCMV UL97 (viral protein kinase) gene confer resistance to (val)ganciclovir and maribavir (Marfori et al., 2007; Piret and Boivin, 2019), while HCMV UL54 (viral DNA polymerase) gene mutations are associated with resistance to foscarnet, cidofovir and (val)ganciclovir (El Chaer et al., 2016). Infection with multiple HCMV genotypes is associated with reduced efficacy of antiviral treatment (Zawilinska et al., 2016; Vinuesa et al., 2017). Importantly, current drugs do not target HCMV during latency, as these drugs target the viral replication machinery, and latency is typified by maintenance of the viral genome without replication. This highlights the potential for clinically relevant recurrence of reactivation following therapy cessation.

Prophylactic administration of Letermovir, a new anti-HCMV agent which inhibits the viral terminase complex, recently demonstrated the capacity to reduce the risk of HCMV disease and all-cause mortality at 24 weeks post-transplant, in a Phase 3 trial (Marty et al., 2017). There are, however, reports emerging of breakthrough viraemia and disease associated with HCMV UL56 terminase mutations conferring Letermovir resistance in HSCT recipients (Lischka et al., 2016; Knoll et al., 2018; Frietsch et al., 2019). Letermovir has now been licensed for HCMV prophylaxis after HSCT and its efficacy in treating refractory or resistant HCMV infection and disease will be evaluated in an upcoming Phase 2 trial (NCT03728426). Given its unique mechanism of action, combination therapy of Letermovir with other currently licensed antivirals (Wildum et al., 2015) may represent a means to more effectively control HCMV and limit the emergence of antiviral drug resistance in HSCT patients, although this area remains to be explored.

Pre-emptive treatment based on viral DNAemia surveillance (Emery et al., 2000) minimizes toxic drug exposure and reduces rates of HCMV disease and mortality (Einsele et al., 1995; Ljungman et al., 1998; Reusser et al., 2002), but there is no consensus on the appropriate plasma viral load threshold for initiating such therapy (Green et al., 2012; Tan et al., 2015; Green et al., 2016; Hanna et al., 2017). Inter-laboratory assays for HCMV DNA quantitation vary and the WHO reference standard for HCMV DNA lacks commutability in many assays (Hayden et al., 2015). Lower viral load thresholds may be required in settings of corticosteroid treatment and T-cell depletion (Green et al., 2012; Melendez-Munoz et al., 2019). Monitoring both HCMV-specific T-cell immunity and viral load has recently been successfully applied to guide the withholding or early discontinuation of antiviral treatment (Avetisyan et al., 2007; Navarro et al., 2016; Kumar et al., 2017). Further to characterizing immune reconstitution profiles in patients who spontaneously resolve reactivation without antiviral treatment (Camargo et al., 2019), more detailed investigation of the immune environment prior to the detection of HCMV DNAemia should be a focus of future studies to optimize the identification of high-risk patients and timing of pre-emptive therapy.

Pooled HCMV-specific or polyclonal intravenous immunoglobulin is not effective at preventing reactivation or reducing mortality when used in the treatment of HCMV pneumonia post-HSCT (Raanani et al., 2009; Erard et al., 2015), although strain-specific antibody therapy was recently shown to potently inhibit murine cytomegalovirus (MCMV) reactivation after bone-marrow transplantation in a preclinical murine model (Martins et al., 2019). Adoptive HCMV-specific T-cell therapies to prevent and treat reactivation after HSCT have been developed 
since the early 1990s (Riddell et al., 1992; Walter et al., 1995; Mackinnon et al., 2008). Third-party- or stem cell donor-derived HCMV-specific T-cells expanded ex vivo or isolated directly with HCMV-specific tetramers and infused in the post-transplant period can accelerate $\mathrm{HCMV}$-specific immune recovery and contribute to long-term control of reactivation and protection from HCMV disease (Peggs et al., 2009; Peggs et al., 2011; Neuenhahn et al., 2017; Withers et al., 2017). The post-transplant infusion of donor-derived HCMV-specific cytotoxic T-cells was shown to reduce the requirement for antiviral drug therapy in a Phase 2 trial (Blyth et al., 2013). Further studies are needed to determine the optimal timing of adoptive cell infusion and understand its impact on post-transplant immune reconstitution.

\section{CONCLUSION}

HCMV is a highly prevalent, opportunistic pathogen that continues to cause substantial morbidity and mortality after HSCT. Improved knowledge of the cellular sites of HCMV latency and the conditions which enable its reactivation to clinically significant infection will be needed to better predict, prevent and control reactivation post-HSCT. Future strategies might involve the selective depletion of latently infected cells from the graft (Krishna et al., 2016, 2017), plasma metabolomics profiling to predict the emergence of reactivation (Monleon et al., 2018), the vaccination of transplant recipients and donors to enhance HCMV-specific immune reconstitution (KharfanDabaja et al., 2012; Ma et al., 2018), or the engineering

\section{REFERENCES}

Admiraal, R., de Koning, C. C. H., Lindemans, C. A., Bierings, M. B., Wensing, A. M. J., Versluys, A. B., et al. (2017). Viral reactivations and associated outcomes in the context of immune reconstitution after pediatric hematopoietic cell transplantation. J. Allergy Clin. Immunol. 140, 1643-1650.e9. doi: 10.1016/ j.jaci.2016.12.992

Aubert, G., Hassan-Walker, A. F., Madrigal, J. A., Emery, V. C., Morte, C., Grace, S., et al. (2001). Cytomegalovirus-specific cellular immune responses and viremia in recipients of allogeneic stem cell transplants. J. Infect. Dis. 184, 955-963. doi: $10.1086 / 323354$

Avdic, S., McSharry, B. P., and Slobedman, B. (2014). Modulation of dendritic cell functions by viral IL-10 encoded by human cytomegalovirus. Front. Microbiol. 5:337. doi: 10.3389/fmicb.2014.00337

Avetisyan, G., Aschan, J., Hägglund, H., Ringdén, O., and Ljungman, P. (2007). Evaluation of intervention strategy based on CMV-specific immune responses after allogeneic SCT. Bone Marrow Transplant. 40, 865-869. doi: 10.1038/sj. bmt. 1705825

Bhutani, D., Dyson, G., Manasa, R., Deol, A., Ratanatharathorn, V., Ayash, L., et al. (2015). Incidence, risk factors, and outcome of cytomegalovirus viremia and gastroenteritis in patients with gastrointestinal graft-versus-host disease. Biol. Blood Marrow Transplant. 21, 159-164. doi: 10.1016/j.bbmt.2014.10.004

Blyth, E., Clancy, L., Simms, R., Ma, C. K. K., Burgess, J., Deo, S., et al. (2013). Donor-derived CMV-specific T cells reduce the requirement for CMV-directed pharmacotherapy after allogeneic stem cell transplantation. Blood 121, 37453758. doi: 10.1182/blood-2012-08-448977

Boeckh, M., Gooley, T. A., Myerson, D., Cunningham, T., Schoch, G., and Bowden, R. A. (1996). Cytomegalovirus pp65 antigenemia-guided early treatment with ganciclovir versus ganciclovir at engraftment after allogeneic marrow transplantation: a randomized double-blind study. Blood 88, 4063-4071. of corticosteroid-resistant HCMV-specific T-cells to improve adoptive cell therapies (Menger et al., 2015). The marked impact of HCMV on post-transplant immune reconstitution warrants continued research to understand its relationship with patient outcomes. New therapeutic approaches for reactivation are actively being pursued and it is hoped these will lessen the clinical impact of reactivation after HSCT in the near future.

\section{AUTHOR CONTRIBUTIONS}

LS and BW generated the initial draft of the manuscript. All authors contributed to the subsequent writing and review of the manuscript.

\section{FUNDING}

This work was funded by a Biomed Connect Grant (University of Sydney) awarded to BS and EB and an Australian Government Research Training Program Scholarship awarded to LS. EB is a NSW Cancer Institute Research Fellow.

\section{ACKNOWLEDGMENTS}

The authors wish to acknowledge the many research groups who have contributed to a better understanding of HCMV latency and reactivation in HSCT patients, and apologize to those whose work has not been cited due to space constraints.

Boeckh, M., Leisenring, W., Riddell, S. R., Bowden, R. A., Huang, M. L., Myerson, D., et al. (2003). Late cytomegalovirus disease and mortality in recipients of allogeneic hematopoietic stem cell transplants: importance of viral load and T-cell immunity. Blood 101, 407-414. doi: 10.1182/blood-2002-030993

Boeckh, M., and Ljungman, P. (2009). How we treat cytomegalovirus in hematopoietic cell transplant recipients. Blood 113, 5711-5719. doi: 10.1182/ blood-2008-10-143560

Boeckh, M., and Nichols, W. G. (2004). The impact of cytomegalovirus serostatus of donor and recipient before hematopoietic stem cell transplantation in the era of antiviral prophylaxis and preemptive therapy. Blood 103, 2003-2008. doi: 10.1182/blood-2003-10-3616

Bolovan-Fritts, C. A., Mocarski, E. S., and Wiedeman, J. A. (1999). Peripheral blood $\mathrm{CD} 14(+)$ cells from healthy subjects carry a circular conformation of latent cytomegalovirus genome. Blood 93, 394-398.

Borchers, S., Bremm, M., Lehrnbecher, T., Dammann, E., Pabst, B., Wölk, B., et al. (2012). Sequential anti-cytomegalovirus response monitoring may allow prediction of cytomegalovirus reactivation after allogeneic stem cell transplantation. PLoS One 7:e50248. doi: 10.1371/journal.pone.0050248

Borchers, S., Luther, S., Lips, U., Hahn, N., Kontsendorn, J., Stadler, M., et al. (2011). Tetramer monitoring to assess risk factors for recurrent cytomegalovirus reactivation and reconstitution of antiviral immunity post allogeneic hematopoietic stem cell transplantation. Transpl. Infect. Dis. 13, 222-236. doi: 10.1111/j.1399-3062.2011.00626.x

Brodin, P., Jojic, V., Gao, T., Bhattacharya, S., Angel, C. J., Furman, D., et al. (2015). Variation in the human immune system is largely driven by non-heritable influences. Cell 160, 37-47. doi: 10.1016/j.cell.2014.12.020

Broers, A. E., van Der Holt, R., van Esser, J. W., Gratama, J. W., Henzen-Logmans, S., Kuenen-Boumeester, V., et al. (2000). Increased transplant-related morbidity and mortality in CMV-seropositive patients despite highly effective prevention 
of CMV disease after allogeneic T-cell-depleted stem cell transplantation. Blood 95, 2240-2245.

Camargo, J. F., Wieder, E. D., Kimble, E., Benjamin, C. L., Kolonias, D. S., Kwon, D., et al. (2019). Deep functional immunophenotyping predicts risk of cytomegalovirus reactivation after hematopoietic cell transplantation. Blood 133, 867-877. doi: 10.1182/blood-2018-10-878918

Campos, A. B., Ribeiro, J., Boutolleau, D., and Sousa, H. (2016). Human cytomegalovirus antiviral drug resistance in hematopoietic stem cell transplantation: current state of the art. Rev. Med. Virol. 26, 161-182. doi: 10.1002/rmv.1873

Cannon, M. J., Schmid, D. S., and Hyde, T. B. (2010). Review of cytomegalovirus seroprevalence and demographic characteristics associated with infection. Rev Med. Virol. 20, 202-213. doi: 10.1002/rmv.655

Cantoni, N., Hirsch, H. H., Khanna, N., Gerull, S., Buser, A., Bucher, C., et al. (2010). Evidence for a bidirectional relationship between cytomegalovirus replication and acute graft-versus-host disease. Biol. Blood Marrow Transplant. 16, 1309-1314. doi: 10.1016/j.bbmt.2010.03.020

Castermans, E., Hannon, M., Dutrieux, J., Humblet-Baron, S., Seidel, L., Cheynier, R., et al. (2011). Thymic recovery after allogeneic hematopoietic cell transplantation with non-myeloablative conditioning is limited to patients younger than 60 years of age. Haematologica 96, 298-306. doi: 10.3324/ haematol.2010.029702

Chemaly, R. F., Chou, S., Einsele, H., Griffiths, P., Avery, R., Razonable, R. R., et al. (2018). Definitions of resistant and refractory cytomegalovirus infection and disease in transplant recipients for use in clinical trials. Clin. Infect. Dis. 68, 1420-1426. doi: 10.1093/cid/ciy696

Chen, C., Busson, M., Rocha, V., Appert, M. L., Lepage, V., Dulphy, N., et al. (2006). Activating KIR genes are associated with CMV reactivation and survival after non-T-cell depleted HLA-identical sibling bone marrow transplantation for malignant disorders. Bone Marrow Transplant. 38, 437-444. doi: 10.1038/ sj.bmt. 1705468

Chen, T., and Hudnall, S. D. (2006). Anatomical mapping of human herpesvirus reservoirs of infection. Mod. Pathol. 19, 726-737. doi: 10.1038/modpathol. 3800584

Chidrawar, S., Khan, N., Wei, W., McLarnon, A., Smith, N., Nayak, L., et al. (2009). Cytomegalovirus-seropositivity has a profound influence on the magnitude of major lymphoid subsets within healthy individuals. Clin. Exp. Immunol. 155, 423-432. doi: 10.1111/j.1365-2249.2008.03785.x

Cho, B. S., Yahng, S. A., Kim, J. H., Yoon, J. H., Shin, S. H., Lee, S. E., et al. (2013). Impact of cytomegalovirus gastrointestinal disease on the clinical outcomes in patients with gastrointestinal graft-versus-host disease in the era of preemptive therapy. Ann. Hematol. 92, 497-504. doi: 10.1007/s00277-0121632-x doi: 10.1007/s00277-012-1632-x

Ciaurriz, M., Beloki, L., Zabalza, A., Bandres, E., Mansilla, C., Perez-Valderrama, E., et al. (2017). Functional specific-T-cell expansion after first cytomegalovirus reactivation predicts viremia control in allogeneic hematopoietic stem cell transplant recipients. Transpl. Infect. Dis. 19:e12778. doi: 10.1111/tid.12778

Cichocki, F., Cooley, S., Davis, Z., DeFor, T. E., Schlums, H., Zhang, B., et al. (2016). CD56dimCD57+NKG2C $+\mathrm{NK}$ cell expansion is associated with reduced leukemia relapse after reduced intensity HCT. Leukemia 30, 456-463. doi: 10.1038/leu.2015.260

Cohen, L., Yeshurun, M., Shpilberg, O., and Ram, R. (2015). Risk factors and prognostic scale for cytomegalovirus (CMV) infection in CMV-seropositive patients after allogeneic hematopoietic cell transplantation. Transpl. Infect. Dis. 17, 510-517. doi: 10.1111/tid.12398

Cook, M., Briggs, D., Craddock, C., Mahendra, P., Milligan, D., Fegan, C., et al. (2006). Donor KIR genotype has a major influence on the rate of cytomegalovirus reactivation following T-cell replete stem cell transplantation. Blood 107, 1230-1232. doi: 10.1182/blood-2005-03-1039

Copelan, E. A. (2006). Hematopoietic stem-cell transplantation. N. Engl. J. Med. 354, 1813-1826.

Craddock, C., Szydlo, R. M., Dazzi, F., Olavarria, E., Cwynarski, K., Yong, A., et al. (2001). Cytomegalovirus seropositivity adversely influences outcome after T-depleted unrelated donor transplant in patients with chronic myeloid leukaemia: the case for tailored graft-versus-host disease prophylaxis. $B r . J$. Haematol. 112, 228-236. doi: 10.1046/j.1365-2141.2001.02519.x

Crocchiolo, R., Bramanti, S., Vai, A., Sarina, B., Mineri, R., Casari, E., et al. (2015). Infections after T-replete haploidentical transplantation and high-dose cyclophosphamide as graft-versus-host disease prophylaxis. Transpl. Infect. Dis. 17, 242-249. doi: 10.1111/tid.12365

Cwynarski, K., Ainsworth, J., Cobbold, M., Wagner, S., Mahendra, P., Apperley, J., et al. (2001). Direct visualization of cytomegalovirus-specific T-cell reconstitution after allogeneic stem cell transplantation. Blood 97, 1232-1240. doi: 10.1182/blood.v97.5.1232

Davis, Z. B., Cooley, S. A., Cichocki, F., Felices, M., Wangen, R., Luo, X., et al. (2015). Adaptive natural killer cell and killer cell immunoglobulin-like receptorexpressing $\mathrm{T}$ cell responses are induced by cytomegalovirus and are associated with protection against cytomegalovirus reactivation after allogeneic donor hematopoietic cell transplantation. Biol. Blood Marrow Transplant. 21, 1653 1662. doi: 10.1016/j.bbmt.2015.05.025

Di Stasi, A., Milton, D. R., Poon, L. M., Hamdi, A., Rondon, G., Chen, J., et al (2014). Similar transplantation outcomes for acute myeloid leukemia and myelodysplastic syndrome patients with haploidentical versus 10/10 human leukocyte antigen-matched unrelated and related donors. Biol. Blood Marrow Transplant. 20, 1975-1981. doi: 10.1016/j.bbmt.2014.08.013

Drylewicz, J., Schellens, I. M., Gaiser, R., Nanlohy, N. M., Quakkelaar, E. D., Otten, H., et al. (2016). Rapid reconstitution of CD4 T cells and NK cells protects against CMV-reactivation after allogeneic stem cell transplantation. J. Transl. Med. 14:230. doi: 10.1186/s12967-016-0988-4

D'Souza, A., and Fretham, C. (2018). Current Uses and Outcomes of Hematopoietic Cell Transplantation (HCT): CIBMTR Summary Slides, 2018. Available at: https: //www.cibmtr.org (accessed March 30, 2019).

Einsele, H., Ehninger, G., Hebart, H., Wittkowski, K. M., Schuler, U., Jahn, G. et al. (1995). Polymerase chain reaction monitoring reduces the incidence of cytomegalovirus disease and the duration and side effects of antiviral therapy after bone marrow transplantation. Blood 86, 2815-2820.

Einsele, H., Ehninger, G., Steidle, M., Fischer, I., Bihler, S., Gerneth, F., et al. (1993). Lymphocytopenia as an unfavorable prognostic factor in patients with cytomegalovirus infection after bone marrow transplantation. Blood 82, 1672 1678.

Einsele, H., Hebart, H., Kauffmann-Schneider, C., Sinzger, C., Jahn, G., Bader, P., et al. (2000). Risk factors for treatment failures in patients receiving PCR-based preemptive therapy for CMV infection. Bone Marrow Transplant. 25, 757-763. doi: $10.1038 /$ sj.bmt.1702226

El Chaer, F., Shah, D. P., and Chemaly, R. F. (2016). How I treat resistant cytomegalovirus infection in hematopoietic cell transplantation recipients. Blood 128, 2624-2636. doi: 10.1182/blood-2016-06-688432

Elmaagacli, A. H., Steckel, N. K., Koldehoff, M., Hegerfeldt, Y., Trenschel, R., Ditschkowski, M., et al. (2011). Early human cytomegalovirus replication after transplantation is associated with a decreased relapse risk: evidence for a putative virus-versus-leukemia effect in acute myeloid leukemia patients. Blood 118, 1402-1412. doi: 10.1182/blood-2010-08-304121

Emery, V. C., Sabin, C. A., Cope, A. V., Gor, D., Hassan-Walker, A. F., and Griffiths, P. D. (2000). Application of viral-load kinetics to identify patients who develop cytomegalovirus disease after transplantation. Lancet 355, 2032-2036. doi: 10.1016/s0140-6736(00)02350-3

Erard, V., Guthrie, K. A., Seo, S., Smith, J., Huang, M., Chien, J., et al. (2015). Reduced mortality of cytomegalovirus pneumonia after hematopoietic cell transplantation due to antiviral therapy and changes in transplantation practices. Clin. Infect. Dis. 61, 31-39. doi: 10.1093/cid/civ215

Espigado, I., de la Cruz-Vicente, F., BenMarzouk-Hidalgo, O. J., Gracia-Ahufinger, I., Garcia-Lozano, J. R., Aguilar-Guisado, M., et al. (2014). Timing of CMVspecific effector memory $\mathrm{T}$ cells predicts viral replication and survival after allogeneic hematopoietic stem cell transplantation. Transpl. Int. 27, 1253-1262. doi: $10.1111 /$ tri. 12406

Fietze, E., Prosch, S., Reinke, P., Stein, J., Docke, W. D., Staffa, G., et al. (1994). Cytomegalovirus infection in transplant recipients. The role of tumor necrosis factor. Transplantation 58, 675-680. doi: 10.1097/00007890-199409270-00007

Fish, K. N., Soderberg-Naucler, C., Mills, L. K., Stenglein, S., and Nelson, J. A. (1998). Human cytomegalovirus persistently infects aortic endothelial cells. J. Virol. 72, 5661-5668.

Foley, B., Cooley, S., Verneris, M. R., Curtsinger, J., Luo, X., Waller, E. K., et al. (2012a). Human cytomegalovirus (CMV)-induced memory-like $\mathrm{NKG} 2 \mathrm{C}(+) \mathrm{NK}$ cells are transplantable and expand in vivo in response to recipient CMV antigen. J. Immunol. 189, 5082-5088. doi: 10.4049/jimmunol. 1201964 
Foley, B., Cooley, S., Verneris, M. R., Pitt, M., Curtsinger, J., Luo, X., et al. (2012b). Cytomegalovirus reactivation after allogeneic transplantation promotes a lasting increase in educated NKG2C + natural killer cells with potent function. Blood 119, 2665-2674. doi: 10.1182/blood-2011-10-386995

Forte, E., Swaminathan, S., Schroeder, M. W., Kim, J. Y., Terhune, S. S., and Hummel, M. (2018). Tumor necrosis factor alpha induces reactivation of human cytomegalovirus independently of myeloid cell differentiation following posttranscriptional establishment of latency. mBio 9:e01560-18. doi: 10.1128/ mBio.01560-18

Foster, A. E., Gottlieb, D. J., Sartor, M., Hertzberg, M. S., and Bradstock, K. F. (2002). Cytomegalovirus-specific CD4+ and CD8+ T-cells follow a similar reconstitution pattern after allogeneic stem cell transplantation. Biol. Blood Marrow Transplant. 8, 501-511. doi: 10.1053/bbmt.2002.v8.pm12374455

Frietsch, J. J., Michel, D., Stamminger, T., Hunstig, F., Birndt, S., Schnetzke, U., et al. (2019). In vivo emergence of UL56 C325Y cytomegalovirus resistance to letermovir in a patient with acute myeloid leukemia after hematopoietic cell transplantation. Mediterr. J. Hematol. Infect. Dis. 11:e2019001. doi: 10.4084/ MJHID.2019.001

Gabanti, E., Lilleri, D., Ripamonti, F., Bruno, F., Zelini, P., Furione, M., et al. (2015). Reconstitution of human cytomegalovirus-specific CD4+ T cells is critical for control of virus reactivation in hematopoietic stem cell transplant recipients but does not prevent organ infection. Biol. Blood Marrow Transplant. 21, 2192-2202. doi: 10.1016/j.bbmt.2015.08.002

Gandhi, M. K., Wills, M. R., Okecha, G., Day, E. K., Hicks, R., Marcus, R. E., et al. (2003). Late diversification in the clonal composition of human cytomegalovirus-specific CD8 + T cells following allogeneic hemopoietic stem cell transplantation. Blood 102, 3427-3438. doi: 10.1182/blood-2002-12-3689

Ganepola, S., Gentilini, C., Hilbers, U., Lange, T., Rieger, K., Hofmann, J., et al. (2007). Patients at high risk for CMV infection and disease show delayed CD8+ T-cell immune recovery after allogeneic stem cell transplantation. Bone Marrow Transplant. 39, 293-299. doi: 10.1038/sj.bmt.1705585

George, B., Kerridge, I. H., Gilroy, N., Huang, G., Hertzberg, M. S., Bradstock, K. F., et al. (2012). A risk score for early cytomegalovirus reactivation after allogeneic stem cell transplantation identifies low-, intermediate-, and high-risk groups: reactivation risk is increased by graft-versus-host disease only in the intermediate-risk group. Transpl. Infect. Dis. 14, 141-148. doi: 10.1111/j.13993062.2011.00706.x

George, B., Pati, N., Gilroy, N., Ratnamohan, M., Huang, G., Kerridge, I., et al. (2010). Pre-transplant cytomegalovirus (CMV) serostatus remains the most important determinant of CMV reactivation after allogeneic hematopoietic stem cell transplantation in the era of surveillance and preemptive therapy. Transpl. Infect. Dis. 12, 322-329. doi: 10.1111/j.1399-3062.2010.00504.x

Gimenez, E., Blanco-Lobo, P., Munoz-Cobo, B., Solano, C., Amat, P., Perez-Romero, P., et al. (2015). Role of cytomegalovirus (CMV)-specific polyfunctional CD8 + T-cells and antibodies neutralizing virus epithelial infection in the control of CMV infection in an allogeneic stem-cell transplantation setting. J. Gen. Virol. 96, 2822-2831. doi: 10.1099/vir.0. 000203

Goldsmith, S. R., Slade, M., DiPersio, J. F., Westervelt, P., Lawrence, S. J., Uy, G. L., et al. (2016). Cytomegalovirus viremia, disease, and impact on relapse in T-cell replete peripheral blood haploidentical hematopoietic cell transplantation with post-transplant cyclophosphamide. Haematologica 101, e465-e468. doi: 10. 3324/haematol.2016.149880

Goodrich, J. M., Bowden, R. A., Fisher, L., Keller, C., Schoch, G., and Meyers, J. D. (1993). Ganciclovir prophylaxis to prevent cytomegalovirus disease after allogeneic marrow transplant. Ann. Intern. Med. 118, 173-178.

Goodrum, F., Jordan, C. T., Terhune, S. S., High, K., and Shenk, T. (2004). Differential outcomes of human cytomegalovirus infection in primitive hematopoietic cell subpopulations. Blood 104, 687-695. doi: 10.1182/blood2003-12- 4344

Gordon, C. L., Miron, M., Thome, J. J., Matsuoka, N., Weiner, J., Rak, M. A., et al. (2017). Tissue reservoirs of antiviral $\mathrm{T}$ cell immunity in persistent human CMV infection. J. Exp. Med. 214, 651-667. doi: 10.1084/jem.2016 0758

Gratama, J. W., Boeckh, M., Nakamura, R., Cornelissen, J. J., Brooimans, R. A., Zaia, J. A., et al. (2010). Immune monitoring with iTAg MHC Tetramers for prediction of recurrent or persistent cytomegalovirus infection or disease in allogeneic hematopoietic stem cell transplant recipients: a prospective multicenter study. Blood 116, 1655-1662. doi: 10.1182/blood-2010-03273508 doi: 10.1182/blood-2010-03-273508

Gratama, J. W., Brooimans, R. A., van der Holt, B., Sintnicolaas, K., van Doornum, G., Niesters, H. G., et al. (2008). Monitoring cytomegalovirus IE-1 and pp65-specific CD4+ and CD8+ T-cell responses after allogeneic stem cell transplantation may identify patients at risk for recurrent CMV reactivations. Cytometry B Clin. Cytom. 74B, 211-220. doi: 10.1002/cyto.b. 20420 doi: $10.1002 /$ cyto.b. 20420

Gratama, J. W., van Esser, J. W., Lamers, C. H., Tournay, C., Lowenberg, B., Bolhuis, R. L., et al. (2001). Tetramer-based quantification of cytomegalovirus (CMV)-specific CD8+ T lymphocytes in T-cell-depleted stem cell grafts and after transplantation may identify patients at risk for progressive CMV infection. Blood 98, 1358-1364. doi: 10.1182/blood.v98.5.1358

Gratwohl, A., Brand, R., Frassoni, F., Rocha, V., Niederwieser, D., Reusser, P., et al. (2005). Cause of death after allogeneic haematopoietic stem cell transplantation (HSCT) in early leukaemias: an EBMT analysis of lethal infectious complications and changes over calendar time. Bone Marrow Transplant. 36, 757-769. doi: 10.1038/sj.bmt.1705140

Green, M. L., Leisenring, W., Stachel, D., Pergam, S. A., Sandmaier, B. M., Wald, A., et al. (2012). Efficacy of a viral load-based, risk-adapted, preemptive treatment strategy for prevention of cytomegalovirus disease after hematopoietic cell transplantation. Biol. Blood Marrow Transplant. 18, 1687-1699. doi: 10.1016/ j.bbmt.2012.05.015

Green, M. L., Leisenring, W., Xie, H., Mast, T. C., Cui, Y., Sandmaier, B. M., et al. (2016). Cytomegalovirus viral load and mortality after haemopoietic stem cell transplantation in the era of pre-emptive therapy: a retrospective cohort study. Lancet Haematol. 3, e119-e127. doi: 10.1016/S2352-3026(15)00289-6

Green, M. L., Leisenring, W. M., Xie, H., Walter, R. B., Mielcarek, M., Sandmaier, B. M., et al. (2013). CMV reactivation after allogeneic HCT and relapse risk: evidence for early protection in acute myeloid leukemia. Blood 122, 1316-1324. doi: 10.1182/blood-2013-02-487074

Hadrup, S. R., Strindhall, J., Kollgaard, T., Seremet, T., Johansson, B., Pawelec, G., et al. (2006). Longitudinal studies of clonally expanded CD8 T cells reveal a repertoire shrinkage predicting mortality and an increased number of dysfunctional cytomegalovirus-specific T cells in the very elderly. J. Immunol. 176, 2645-2653. doi: 10.4049/jimmunol.176.4.2645

Hahn, G., Jores, R., and Mocarski, E. S. (1998). Cytomegalovirus remains latent in a common precursor of dendritic and myeloid cells. Proc. Natl. Acad. Sci. U.S.A. 95, 3937-3942. doi: 10.1073/pnas.95.7.3937

Hakki, M., Riddell, S. R., Storek, J., Carter, R. A., Stevens-Ayers, T., Sudour, P., et al. (2003). Immune reconstitution to cytomegalovirus after allogeneic hematopoietic stem cell transplantation: impact of host factors, drug therapy, and subclinical reactivation. Blood 102, 3060-3067. doi: 10.1182/blood-200211-3472

Hall, C. E., Koparde, V. N., Jameson-Lee, M., Elnasseh, A. G., Scalora, A. F., Kobulnicky, D. J., et al. (2017). Sequence homology between HLA-bound cytomegalovirus and human peptides: a potential trigger for alloreactivity. PLoS One 12:e0178763. doi: 10.1371/journal.pone.0178763

Hammer, Q., Ruckert, T., Borst, E. M., Dunst, J., Haubner, A., Durek, P., et al. (2018). Peptide-specific recognition of human cytomegalovirus strains controls adaptive natural killer cells. Nat. Immunol. 19, 453-463. doi: 10.1038/s41590018-0082-6

Hanna, Z., Karrick, M., Jayaprakash, R., Morgan, W., Lutfi, S., Gunasekaran, K., et al. (2017). Establishing the optimal viral load threshold for initiation of therapy for cytomegalovirus infection in hematopoietic stem cell transplant recipients: a prospective derivation cohort study using the international standardized CMV quantitative nucleic acid testing. Open Forum Infect. Dis. 4(Suppl._1), S713-S714.

Hargett, D., and Shenk, T. E. (2010). Experimental human cytomegalovirus latency in CD14+ monocytes. Proc. Natl. Acad. Sci. U.S.A. 107, 20039-20044. doi: 10.1073/pnas.1014509107

Hayden, R. T., Preiksaitis, J., Tong, Y., Pang, X., Sun, Y., Tang, L., et al. (2015). Commutability of the first world health organization international standard for human cytomegalovirus. J. Clin. Microbiol. 53, 3325-3333. doi: 10.1128/JCM. 01495- 15

Hendrix, R. M., Wagenaar, M., Slobbe, R. L., and Bruggeman, C. A. (1997). Widespread presence of cytomegalovirus DNA in tissues of healthy trauma victims. J. Clin. Pathol. 50, 59-63. doi: 10.1136/jcp.50.1.59 
Hill, J. A., Mayer, B. T., Xie, H., Leisenring, W. M., Huang, M. L., StevensAyers, T., et al. (2017). The cumulative burden of double-stranded DNA virus detection after allogeneic HCT is associated with increased mortality. Blood 129, 2316-2325. doi: 10.1182/blood-2016-10-748426

Hiwarkar, P., Gaspar, H. B., Gilmour, K., Jagani, M., Chiesa, R., Bennett-Rees, N., et al. (2013). Impact of viral reactivations in the era of pre-emptive antiviral drug therapy following allogeneic haematopoietic SCT in paediatric recipients. Bone Marrow Transplant. 48, 803-808. doi: 10.1038/bmt.2012.221

Huang, M. M., Kew, V. G., Jestice, K., Wills, M. R., and Reeves, M. B. (2012). Efficient human cytomegalovirus reactivation is maturation dependent in the Langerhans dendritic cell lineage and can be studied using a CD14+ experimental latency model. J. Virol. 86, 8507-8515. doi: 10.1128/JVI.00598-12

Ibanez, C. E., Schrier, R., Ghazal, P., Wiley, C., and Nelson, J. A. (1991). Human cytomegalovirus productively infects primary differentiated macrophages. J. Virol. 65, 6581-6588.

Ito, S., Pophali, P., Co, W., Koklanaris, E. K., Superata, J., Fahle, G. A., et al. (2013). CMV reactivation is associated with a lower incidence of relapse after allo-SCT for CML. Bone Marrow Transplant. 48, 1313-1316. doi: 10.1038/bmt.2013.49

Itzykson, R., Robin, M., Moins-Teisserenc, H., Delord, M., Busson, M., Xhaard, A., et al. (2015). Cytomegalovirus shapes long-term immune reconstitution after allogeneic stem cell transplantation. Haematologica 100, 114-123. doi: 10.3324/haematol.2014.113415

Janeczko, M., Mielcarek, M., Rybka, B., Ryczan-Krawczyk, R., NoworolskaSauren, D., and Kalwak, K. (2016). Immune recovery and the risk of $\mathrm{CMV} / \mathrm{EBV}$ reactivation in children post allogeneic haematopoietic stem cell transplantation. Cent. Eur. J. Immunol. 41, 287-296. doi: 10.5114/ceji.2016. 63129

Jang, J. E., Hyun, S. Y., Kim, Y. D., Yoon, S. H., Hwang, D. Y., Kim, S. J., et al. (2012). Risk factors for progression from cytomegalovirus viremia to cytomegalovirus disease after allogeneic hematopoietic stem cell transplantation. Biol. Blood Marrow Transplant. 18, 881-886. doi: 10.1016/j.bbmt.2011.10.037

Jeljeli, M., Guerin-El Khourouj, V., Porcher, R., Fahd, M., Leveille, S., Yakouben, K., et al. (2014). Relationship between cytomegalovirus (CMV) reactivation, CMVdriven immunity, overall immune recovery and graft-versus-leukaemia effect in children. Br. J. Haematol. 166, 229-239. doi: 10.1111/bjh. 12875

Jenkins, C., Abendroth, A., and Slobedman, B. (2004). A novel viral transcript with homology to human interleukin-10 is expressed during latent human cytomegalovirus infection. J. Virol. 78, 1440-1447. doi: 10.1128/jvi.78.3.14401447.2004

Kawasaki, S., Oshitani, H., Suzuki, H., Arakawa, M., Mizuta, K., Imaizumi, M., et al. (1999). PCR-RFLP analysis of cytomegalovirus infections associated with bone marrow transplantation in Japanese children. Microbiol. Immunol. 43, 359-364. doi: 10.1111/j.1348-0421.1999.tb02416.x

Khaiboullina, S. F., Maciejewski, J. P., Crapnell, K., Spallone, P. A., Dean Stock, A., Pari, G. S., et al. (2004). Human cytomegalovirus persists in myeloid progenitors and is passed to the myeloid progeny in a latent form. Br. J. Haematol. 126, 410-417. doi: 10.1111/j.1365-2141.2004.05056.x

Khan, N., Shariff, N., Cobbold, M., Bruton, R., Ainsworth, J. A., Sinclair, A. J., et al. (2002). Cytomegalovirus seropositivity drives the CD8 T cell repertoire toward greater clonality in healthy elderly individuals. J. Immunol. 169, 1984-1992. doi: 10.4049/jimmunol.169.4.1984

Kharfan-Dabaja, M. A., Boeckh, M., Wilck, M. B., Langston, A. A., Chu, A. H., Wloch, M. K., et al. (2012). A novel therapeutic cytomegalovirus DNA vaccine in allogeneic haemopoietic stem-cell transplantation: a randomised, doubleblind, placebo-controlled, phase 2 trial. Lancet Infect. Dis. 12, 290-299. doi: 10.1016/S1473-3099(11)70344-9

Kheav, V. D., Busson, M., Scieux, C., Peffault de Latour, R., Maki, G., Haas, P., et al. (2014). Favorable impact of natural killer cell reconstitution on chronic graft-versus-host disease and cytomegalovirus reactivation after allogeneic hematopoietic stem cell transplantation. Haematologica 99, 1860-1867. doi: 10.3324/haematol.2014.108407

Kim, D. H., Kim, J. G., Lee, N. Y., Sung, W. J., Sohn, S. K., Suh, J. S., et al. (2004). Risk factors for late cytomegalovirus infection after allogeneic stem cell transplantation using HLA-matched sibling donor: donor lymphocyte infusion and previous history of early CMV infection. Bone Marrow Transplant. 34, 21-27. doi: 10.1038/sj.bmt.1704528

Knight, A., Madrigal, A. J., Grace, S., Sivakumaran, J., Kottaridis, P., Mackinnon, S., et al. (2010). The role of Vdelta2-negative gamma delta $\mathrm{T}$ cells during cytomegalovirus reactivation in recipients of allogeneic stem cell transplantation. Blood 116, 2164-2172. doi: 10.1182/blood-2010-01-255166

Knoll, B. M., Seiter, K., Phillips, A., and Soave, R. (2018). Breakthrough cytomegalovirus pneumonia in hematopoietic stem cell transplant recipient on letermovir prophylaxis. Bone Marrow Transplant. .

Krishna, B. A., Lau, B., Jackson, S. E., Wills, M. R., Sinclair, J. H., and Poole, E. (2016). Transient activation of human cytomegalovirus lytic gene expression during latency allows cytotoxic T cell killing of latently infected cells. Sci. Rep. 6:24674. doi: $10.1038 /$ srep24674

Krishna, B. A., Spiess, K., Poole, E. L., Lau, B., Voigt, S., Kledal, T. N., et al. (2017). Targeting the latent cytomegalovirus reservoir with an antiviral fusion toxin protein. Nat. Commun. 8:14321. doi: 10.1038/ncomms14321

Krol, L., Stuchly, J., Hubacek, P., Keslova, P., Sedlacek, P., Stary, J., et al. (2011). Signature profiles of CMV-specific T-cells in patients with CMV reactivation after hematopoietic SCT. Bone Marrow Transplant. 46, 1089-1098. doi: 10. 1038/bmt.2010.261

Kumar, D., Mian, M., Singer, L., and Humar, A. (2017). An interventional study using cell-mediated immunity to personalize therapy for cytomegalovirus infection after transplantation. Am. J. Transplant. 17, 2468-2473. doi: 10.1111/ ajt.14347

Lakshmikanth, T., Olin, A., Chen, Y., Mikes, J., Fredlund, E., Remberger, M., et al. (2017). Mass cytometry and topological data analysis reveal immune parameters associated with complications after allogeneic stem cell transplantation. Cell Rep. 20, 2238-2250. doi: 10.1016/j.celrep.2017.08.021

Larsson, K., Aschan, J., Remberger, M., Ringden, O., Winiarski, J., and Ljungman, P. (2004). Reduced risk for extensive chronic graft-versus-host disease in patients receiving transplants with human leukocyte antigen-identical sibling donors given polymerase chain reaction-based preemptive therapy against cytomegalovirus. Transplantation 77, 526-531. doi: 10.1097/01.tp.0000109778. 39235.f4

Li, C. R., Greenberg, P. D., Gilbert, M. J., Goodrich, J. M., and Riddell, S. R. (1994). Recovery of HLA-restricted cytomegalovirus (CMV)-specific T-cell responses after allogeneic bone marrow transplant: correlation with CMV disease and effect of ganciclovir prophylaxis. Blood 83, 1971-1979.

Lilleri, D., Fornara, C., Chiesa, A., Caldera, D., Alessandrino, E. P., and Gerna, G. (2008). Human cytomegalovirus-specific CD4+ and CD8+ T-cell reconstitution in adult allogeneic hematopoietic stem cell transplant recipients and immune control of viral infection. Haematologica 93, 248-256. doi: 10. 3324/haematol.11912

Lilleri, D., Gerna, G., Fornara, C., Chiesa, A., Comolli, G., Zecca, M., et al. (2009). Human cytomegalovirus-specific T cell reconstitution in young patients receiving $\mathrm{T}$ cell-depleted, allogeneic hematopoietic stem cell transplantation. J. Infect. Dis. 199, 829-836. doi: 10.1086/597123

Lilleri, D., Gerna, G., Fornara, C., Lozza, L., Maccario, R., and Locatelli, F. (2006). Prospective simultaneous quantification of human cytomegalovirusspecific CD4+ and CD8 + T-cell reconstitution in young recipients of allogeneic hematopoietic stem cell transplants. Blood 108, 1406-1412. doi: 10.1182/blood2005-11-012864

Lilleri, D., Gerna, G., Zelini, P., Chiesa, A., Rognoni, V., Mastronuzzi, A., et al. (2012). Monitoring of human cytomegalovirus and virus-specific T-cell response in young patients receiving allogeneic hematopoietic stem cell transplantation. PLoS One 7:e41648. doi: 10.1371/journal.pone.0041648

Lindau, P., Mukherjee, R., Gutschow, M. V., Vignali, M., Warren, E. H., Riddell, S. R., et al. (2019). Cytomegalovirus exposure in the elderly does not reduce CD8 T cell repertoire diversity. J. Immunol. 202, 476-483. doi: 10.4049/jimmunol. 1800217

Link, C. S., Eugster, A., Heidenreich, F., Rucker-Braun, E., Schmiedgen, M., Oelschlagel, U., et al. (2016). Abundant cytomegalovirus (CMV) reactive clonotypes in the CD8 $(+) \mathrm{T}$ cell receptor alpha repertoire following allogeneic transplantation. Clin. Exp. Immunol. 184, 389-402. doi: 10.1111/cei.12770

Lischka, P., Michel, D., and Zimmermann, H. (2016). Characterization of cytomegalovirus breakthrough events in a phase 2 prophylaxis trial of letermovir (AIC246, MK 8228). J. Infect. Dis. 213, 23-30. doi: 10.1093/infdis/ jiv352

Liu, J., Chang, Y. J., Yan, C. H., Xu, L. P., Jiang, Z. F., Zhang, X. H., et al. (2016). Poor CMV-specific CD8 + T central memory subset recovery at early stage postHSCT associates with refractory and recurrent CMV reactivation. J. Infect. 73, 261-270. doi: 10.1016/j.jinf.2016.04.033 
Liu, J., Kong, J., Chang, Y. J., Chen, H., Chen, Y. H., Han, W., et al. (2015). Patients with refractory cytomegalovirus (CMV) infection following allogeneic haematopoietic stem cell transplantation are at high risk for CMV disease and non-relapse mortality. Clin. Microbiol. Infect. 21, 1121.e9-1121.e15. doi: 10.1016/j.cmi.2015.06.009

Ljungman, P., Aschan, J., Lewensohn-Fuchs, I., Carlens, S., Larsson, K., Lonnqvist, B., et al. (1998). Results of different strategies for reducing: cytomegalovirus-associated mortality in allogeneic stem cell transplant recipients. Transplantation 66, 1330-1334. doi: 10.1097/00007890-19981127000012

Ljungman, P., Brand, R., Einsele, H., Frassoni, F., Niederwieser, D., and Cordonnier, C. (2003). Donor CMV serologic status and outcome of CMVseropositive recipients after unrelated donor stem cell transplantation: an EBMT megafile analysis. Blood 102, 4255-4260. doi: 10.1182/blood-2002-103263

Ljungman, P., Brand, R., Hoek, J., de la Camara, R., Cordonnier, C., Einsele, H., et al. (2014). Donor cytomegalovirus status influences the outcome of allogeneic stem cell transplant: a study by the European group for blood and marrow transplantation. Clin. Infect. Dis. 59, 473-481. doi: 10.1093/cid/ciu364

Ljungman, P., de la Camara, R., Cordonnier, C., Einsele, H., Engelhard, D., Reusser, P., et al. (2008). Management of CMV, HHV-6, HHV-7 and Kaposi-sarcoma herpesvirus (HHV-8) infections in patients with hematological malignancies and after SCT. Bone Marrow Transplant. 42, 227-240. doi: 10.1038/bmt.2008. 162

Ljungman, P., Deliliers, G. L., Platzbecker, U., Matthes-Martin, S., Bacigalupo, A., Einsele, H., et al. (2001). Cidofovir for cytomegalovirus infection and disease in allogeneic stem cell transplant recipients. The infectious diseases working party of the European group for blood and marrow transplantation. Blood 97, 388-392. doi: 10.1182/blood.v97.2.388

Ljungman, P., Perez-Bercoff, L., Jonsson, J., Avetisyan, G., Sparrelid, E., Aschan, J., et al. (2006). Risk factors for the development of cytomegalovirus disease after allogeneic stem cell transplantation. Haematologica 91, 78-83.

Lonnqvist, B., Ringden, O., Ljungman, P., Wahren, B., and Gahrton, G. (1986). Reduced risk of recurrent leukaemia in bone marrow transplant recipients after cytomegalovirus infection. Br. J. Haematol. 63, 671-679. doi: 10.1111/j.13652141.1986.tb07551.x

Lonnqvist, B., Ringden, O., Wahren, B., Gahrton, G., and Lundgren, G. (1984). Cytomegalovirus infection associated with and preceding chronic graft-versushost disease. Transplantation 38, 465-468. doi: 10.1097/00007890-19841100000004

Lugthart, G., van Ostaijen-Ten Dam, M. M., Jol-van der Zijde, C. M., van Holten, T. C., Kester, M. G., Heemskerk, M. H., et al. (2014). Early cytomegalovirus reactivation leaves a specific and dynamic imprint on the reconstituting $\mathrm{T}$ cell compartment long-term after hematopoietic stem cell transplantation. Biol. Blood Marrow Transplant. 20, 655-661. doi: 10.1016/j.bbmt.2014.01.018

Ma, C. K. K., Clancy, L., Simms, R., Burgess, J., Deo, S., Blyth, E., et al. (2018). Adjuvant peptide pulsed dendritic cell vaccination in addition to $\mathrm{T}$ cell adoptive immunotherapy for cytomegalovirus infection in allogeneic hematopoietic stem cell transplantation recipients. Biol. Blood Marrow Transplant. 24, 71-77. doi: 10.1016/j.bbmt.2017.08.028

Mackinnon, S., Thomson, K., Verfuerth, S., Peggs, K., and Lowdell, M. (2008). Adoptive cellular therapy for cytomegalovirus infection following allogeneic stem cell transplantation using virus-specific T cells. Blood Cells Mol. Dis. 40, 63-67. doi: 10.1016/j.bcmd.2007.07.003

Marfori, J. E., Exner, M. M., Marousek, G. I., Chou, S., and Drew, W. L. (2007). Development of new cytomegalovirus UL97 and DNA polymerase mutations conferring drug resistance after valganciclovir therapy in allogeneic stem cell recipients. J. Clin. Virol. 38, 120-125. doi: 10.1016/j.jcv.2006. 11.005

Mariotti, J., Maura, F., Spina, F., Roncari, L., Dodero, A., Farina, L., et al. (2014). Impact of cytomegalovirus replication and cytomegalovirus serostatus on the outcome of patients with B cell lymphoma after allogeneic stem cell transplantation. Biol. Blood Marrow Transplantat. 20, 885-890. doi: 10.1016/ j.bbmt.2014.02.015

Martins, J. P., Andoniou, C. E., Fleming, P., Kuns, R. D., Schuster, I. S., Voigt, V., et al. (2019). Strain-specific antibody therapy prevents cytomegalovirus reactivation after transplantation. Science 363, 288-293. doi: 10.1126/science. aat0066
Marty, F. M., Ljungman, P., Chemaly, R. F., Maertens, J., Dadwal, S. S., Duarte, R. F., et al. (2017). Letermovir prophylaxis for cytomegalovirus in hematopoietic-cell transplantation. N. Engl. J. Med. 377, 2433-2444. doi: 10. 1056/NEJMoa1706640

McSharry, B. P., Avdic, S., and Slobedman, B. (2012). Human cytomegalovirus encoded homologs of cytokines, chemokines and their receptors: roles in immunomodulation. Viruses 4, 2448-2470. doi: 10.3390/v411| 2448 doi: $10.3390 / \mathrm{v} 4112448$

Melendez-Munoz, R., Marchalik, R., Jerussi, T., Dimitrova, D., Nussenblatt, V., Beri, A., et al. (2019). Cytomegalovirus infection incidence and risk factors across diverse hematopoietic cell transplantation platforms using a standardized monitoring and treatment approach: a comprehensive evaluation from a single institution. Biol. Blood Marrow Transplant. 25, 577-586. doi: 10.1016/j.bbmt.2018.10.011

Mendelson, M., Monard, S., Sissons, P., and Sinclair, J. (1996). Detection of endogenous human cytomegalovirus in $\mathrm{CD} 34+$ bone marrow progenitors. J. Gen. Virol. 77(Pt 12), 3099-3102. doi: 10.1099/0022-1317-77-12-3099

Menger, L., Gouble, A., Marzolini, M. A., Pachnio, A., Bergerhoff, K., Henry, J. Y., et al. (2015). TALEN-mediated genetic inactivation of the glucocorticoid receptor in cytomegalovirus-specific T cells. Blood 126, 2781-2789. doi: 10. 1182/blood-2015-08-664755

Miller, W., Flynn, P., McCullough, J., Balfour, H. J., Goldman, A., Haake, R., et al. (1986). Cytomegalovirus infection after bone marrow transplantation: an association with acute graft-v-host disease. Blood 67, 1162-1167.

Minton, E. J., Tysoe, C., Sinclair, J. H., and Sissons, J. G. (1994). Human cytomegalovirus infection of the monocyte/macrophage lineage in bone marrow. J. Virol. 68, 4017-4021.

Moins-Teisserenc, H., Busson, M., Scieux, C., Bajzik, V., Cayuela, J. M., Clave, E., et al. (2008). Patterns of cytomegalovirus reactivation are associated with distinct evolutive profiles of immune reconstitution after allogeneic hematopoietic stem cell transplantation. J. Infect. Dis. 198, 818-826. doi: 10. $1086 / 591185$

Monleon, D., Talaya, A., Gimenez, E., Vinuesa, V., Morales, J. M., HernandezBoluda, J. C., et al. (2018). Validation of a plasma metabolomics model that allows anticipation of the occurrence of cytomegalovirus DNAaemia in allogeneic stem cell transplant recipients. J. Med. Microbiol. .

Muccio, L., Bertaina, A., Falco, M., Pende, D., Meazza, R., Lopez-Botet, M., et al. (2016). Analysis of memory-like natural killer cells in human cytomegalovirusinfected children undergoing $\alpha \beta+\mathrm{T}$ and B cell-depleted hematopoietic stem cell transplantation for hematological malignancies. Haematologica 101, 371-381. doi: 10.3324/haematol.2015.134155

Munoz-Cobo, B., Solano, C., Benet, I., Costa, E., Remigia, M. J., de la Camara, R., et al. (2012). Functional profile of cytomegalovirus (CMV)-specific CD8+ $\mathrm{T}$ cells and kinetics of NKG2C $+\mathrm{NK}$ cells associated with the resolution of CMV DNAemia in allogeneic stem cell transplant recipients. J. Med. Virol. 84, 259-267. doi: 10.1002/jmv.22254

Nakamura, R., Battiwalla, M., Solomon, S., Follmann, D., Chakrabarti, S., Cortez, K., et al. (2004). Persisting posttransplantation cytomegalovirus antigenemia correlates with poor lymphocyte proliferation to cytomegalovirus antigen and predicts for increased late relapse and treatment failure. Biol. Blood Marrow Transplantat. 10, 49-57. doi: 10.1016/j.bbmt.2003.08.011

Nann-Rütti, S., Tzankov, A., Cantoni, N., Halter, J., Heim, D., Tsakiris, D., et al. (2012). Large granular lymphocyte expansion after allogeneic hematopoietic stem cell transplant is associated with a cytomegalovirus reactivation and shows an indolent outcome. Biol. Blood Marrow Transplant. 18, 1765-1770. doi: 10. 1016/j.bbmt.2012.07.007

Navarro, D., Amat, P., de la Camara, R., Lopez, J., Vazquez, L., Serrano, D., et al. (2016). Efficacy and safety of a preemptive antiviral therapy strategy based on combined virological and immunological monitoring for active cytomegalovirus infection in allogeneic stem cell transplant recipients. Open Forum Infect. Dis. 3:ofw107. doi: 10.1093/ofid/ofw107

Neuenhahn, M., Albrecht, J., Odendahl, M., Schlott, F., Dossinger, G., Schiemann, M., et al. (2017). Transfer of minimally manipulated CMV-specific T cells from stem cell or third-party donors to treat CMV infection after allo-HSCT. Leukemia 31, 2161-2171. doi: 10.1038/leu.2017.16

Nichols, W. G., Corey, L., Gooley, T., Davis, C., and Boeckh, M. (2002). High risk of death due to bacterial and fungal infection among cytomegalovirus (CMV)seronegative recipients of stem cell transplants from seropositive donors: 
evidence for indirect effects of primary CMV infection. J. Infect. Dis. 185, 273-282. doi: 10.1086/338624

Ogonek, J., Varanasi, P., Luther, S., Schweier, P., Kuhnau, W., Gohring, G., et al. (2017). Possible impact of cytomegalovirus-specific CD8(+) T cells on immune reconstitution and conversion to complete donor chimerism after allogeneic stem cell transplantation. Biol. Blood Marrow Transplant. 23, 1046-1053. doi: 10.1016/j.bbmt.2017.03.027

Ozdemir, E., St John, L. S., Gillespie, G., Rowland-Jones, S., Champlin, R. E., Molldrem, J. J., et al. (2002). Cytomegalovirus reactivation following allogeneic stem cell transplantation is associated with the presence of dysfunctional antigen-specific CD8+ T cells. Blood 100, 3690-3697. doi: 10.1182/blood2002-05-1387

Pampou, S., Gnedoy, S. N., Bystrevskaya, V. B., Smirnov, V. N., Chazov, E. I., Melnick, J. L., et al. (2000). Cytomegalovirus genome and the immediate-early antigen in cells of different layers of human aorta. Virchows Arch. 436, 539-552. doi: $10.1007 / \mathrm{s} 004289900173$

Patin, E., Hasan, M., Bergstedt, J., Rouilly, V., Libri, V., Urrutia, A., et al. (2018). Natural variation in the parameters of innate immune cells is preferentially driven by genetic factors. Nat. Immunol. 19, 302-314. doi: 10.1038/s41590-0180049-7

Peggs, K. S., Thomson, K., Samuel, E., Dyer, G., Armoogum, J., Chakraverty, R., et al. (2011). Directly selected cytomegalovirus-reactive donor T cells confer rapid and safe systemic reconstitution of virus-specific immunity following stem cell transplantation. Clin. Infect. Dis. 52, 49-57. doi: 10.1093/cid/ciq042

Peggs, K. S., Verfuerth, S., Pizzey, A., Chow, S. L., Thomson, K., and Mackinnon, S. (2009). Cytomegalovirus-specific $\mathrm{T}$ cell immunotherapy promotes restoration of durable functional antiviral immunity following allogeneic stem cell transplantation. Clin. Infect. Dis. 49, 1851-1860. doi: 10.1086/648422

Pelak, O., Stuchly, J., Krol, L., Hubacek, P., Keslova, P., Sedlacek, P., et al. (2017). Appearance of cytomegalovirus-specific T-cells predicts fast resolution of viremia post hematopoietic stem cell transplantation. Cytometry B Clin. Cytom. 92, 380-388. doi: 10.1002/cyto.b.21348

Peric, Z., Wilson, J., Durakovic, N., Ostojic, A., Desnica, L., Vranjes, V. R., et al. (2018). Early human cytomegalovirus reactivation is associated with lower incidence of relapse of myeloproliferative disorders after allogeneic hematopoietic stem cell transplantation. Bone Marrow Transplant. 53, 14501456. doi: 10.1038/s41409-018-0172-y

Piret, J., and Boivin, G. (2019). Clinical development of letermovir and maribavir: overview of human cytomegalovirus drug resistance. Antiviral Res. 163, 91-105. doi: 10.1016/j.antiviral.2019.01.011

Poole, E., Juss, J. K., Krishna, B., Herre, J., Chilvers, E. R., and Sinclair, J. (2015). Alveolar macrophages isolated directly from human cytomegalovirus (HCMV)seropositive individuals are sites of HCMV reactivation in vivo. J. Infect. Dis. 211, 1936-1942. doi: 10.1093/infdis/jiu837

Pourgheysari, B., Piper, K. P., McLarnon, A., Arrazi, J., Bruton, R., Clark, F., et al. (2009). Early reconstitution of effector memory CD4+ CMV-specific T cells protects against CMV reactivation following allogeneic SCT. Bone Marrow Transplant. 43, 853-861. doi: 10.1038/bmt.2008.403

Qayed, M., Khurana, M., Hilinski, J., Gillespie, S., McCracken, C., Applegate, K., et al. (2014). Risk for CMV reactivation in children undergoing allogeneic hematopoietic stem cell transplantation. Pediatr. Blood Cancer 62, 364-366. doi: $10.1002 / p b c .25237$

Quinnan, G. V., Kirmani, N., Rook, A. H., Manischewitz, J. F., Jackson, L., Moreschi, G., et al. (1982). Cytotoxic t cells in cytomegalovirus infection: HLArestricted T-lymphocyte and non-T-lymphocyte cytotoxic responses correlate with recovery from cytomegalovirus infection in bone-marrow-transplant recipients. N. Engl. J. Med. 307, 7-13. doi: 10.1056/nejm 198207013070102

Raanani, P., Gafter-Gvili, A., Paul, M., Ben-Bassat, I., Leibovici, L., and Shpilberg, O. (2009). Immunoglobulin prophylaxis in hematopoietic stem cell transplantation: systematic review and meta-analysis. J. Clin. Oncol. 27, 770-781. doi: 10.1200/jco.2008.16.8450

Raeiszadeh, M., Pachnio, A., Begum, J., Craddock, C., Moss, P., and Chen, F. E. (2015). Characterization of CMV-specific CD4+ T-cell reconstitution following stem cell transplantation through the use of HLA Class II-peptide tetramers identifies patients at high risk of recurrent CMV reactivation. Haematologica 100, e318-e322.

Ramanathan, M., Teira, P., Battiwalla, M., Barrett, J., Ahn, K. W., Chen, M., et al. (2016). Impact of early CMV reactivation in cord blood stem cell recipients in the current era. Bone Marrow Transplant. 51, 1113-1120. doi: 10.1038/bmt. 2016.89

Ravens, S., Schultze-Florey, C., Raha, S., Sandrock, I., Drenker, M., Oberdorfer, L., et al. (2017). Human gammadelta $\mathrm{T}$ cells are quickly reconstituted after stem-cell transplantation and show adaptive clonal expansion in response to viral infection. Nat. Immunol. 18, 393-401. doi: 10.1038/ni. 3686

Reeves, M. B., Coleman, H., Chadderton, J., Goddard, M., Sissons, J. G. P., and Sinclair, J. H. (2004). Vascular endothelial and smooth muscle cells are unlikely to be major sites of latency of human cytomegalovirus in vivo. J. Gen. Virol. 85, 3337-3341. doi: 10.1099/vir.0.80285-0

Reeves, M. B., and Compton, T. (2011). Inhibition of inflammatory interleukin-6 activity via extracellular signal-regulated kinase-mitogenactivated protein kinase signaling antagonizes human cytomegalovirus reactivation from dendritic cells. J. Virol. 85, 12750-12758. doi: 10.1128/JVI. 05878-11

Reeves, M. B., Lehner, P. J., Sissons, J. G., and Sinclair, J. H. (2005a). An in vitro model for the regulation of human cytomegalovirus latency and reactivation in dendritic cells by chromatin remodelling. J. Gen. Virol. 86(Pt 11), 2949-2954. doi: 10.1099/vir.0.81161-0

Reeves, M. B., MacAry, P. A., Lehner, P. J., Sissons, J. G., and Sinclair, J. H. (2005b). Latency, chromatin remodeling, and reactivation of human cytomegalovirus in the dendritic cells of healthy carriers. Proc. Natl. Acad. Sci. U.S.A. 102, 4140-4145. doi: 10.1073/pnas.0408994102

Reeves, M. B., and Sinclair, J. H. (2013). Circulating dendritic cells isolated from healthy seropositive donors are sites of human cytomegalovirus reactivation in vivo. J. Virol. 87, 10660-10667. doi: 10.1128/JVI.01539-13

Reusser, P., Einsele, H., Lee, J., Volin, L., Rovira, M., Engelhard, D., et al. (2002). Randomized multicenter trial of foscarnet versus ganciclovir for preemptive therapy of cytomegalovirus infection after allogeneic stem cell transplantation. Blood 99, 1159-1164. doi: 10.1182/blood.v99.4.1159

Reusser, P., Riddell, S. R., Meyers, J. D., and Greenberg, P. D. (1991) Cytotoxic T-lymphocyte response to cytomegalovirus after human allogeneic bone marrow transplantation: pattern of recovery and correlation with cytomegalovirus infection and disease. Blood 78, 1373-1380.

Riddell, S. R., Watanabe, K. S., Goodrich, J. M., Li, C. R., Agha, M. E., and Greenberg, P. D. (1992). Restoration of viral immunity in immunodeficient humans by the adoptive transfer of T cell clones. Science 257, 238-241. doi: 10.1126/science. 1352912

Sacre, K., Nguyen, S., Deback, C., Carcelain, G., Vernant, J. P., Leblond, V., et al. (2008). Expansion of human cytomegalovirus (HCMV) immediate-early 1specific CD8+ T cells and control of HCMV replication after allogeneic stem cell transplantation. J. Virol. 82, 10143-10152. doi: 10.1128/JVI.00688-08

Scheinberg, P., Melenhorst, J. J., Brenchley, J. M., Hill, B. J., Hensel, N. F., Chattopadhyay, P. K., et al. (2009). The transfer of adaptive immunity to CMV during hematopoietic stem cell transplantation is dependent on the specificity and phenotype of CMV-specific T cells in the donor. Blood 114, 5071-5080. doi: 10.1182/blood-2009-04-214684

Scheper, W., van Dorp, S., Kersting, S., Pietersma, F., Lindemans, C., Hol, S., et al. (2013). $\gamma \delta$ T cells elicited by CMV reactivation after allo-SCT cross-recognize CMV and leukemia. Leukemia 27, 1328-1338. doi: 10.1038/leu.2012.374

Schmidt-Hieber, M., Labopin, M., Beelen, D., Volin, L., Ehninger, G., Finke, J., et al. (2013). CMV serostatus still has an important prognostic impact in de novo acute leukemia patients after allogeneic stem cell transplantation: a report from the Acute Leukemia Working Party of EBMT. Blood 122, 3359-3364. doi: 10.1182/blood-2013-05-499830

Servais, S., Dumontier, N., Biard, L., Schnepf, N., Resche-Rigon, M., Peffault de Latour, R., et al. (2016). Response to antiviral therapy in haematopoietic stem cell transplant recipients with cytomegalovirus (CMV) reactivation according to the donor CMV serological status. Clin. Microbiol. Infect. 22, 289.e1-289.e7. doi: 10.1016/j.cmi.2015.11.006

Sester, M., Sester, U., Gartner, B., Kubuschok, B., Girndt, M., Meyerhans, A., et al. (2002). Sustained high frequencies of specific CD4 T cells restricted to a single persistent virus. J. Virol. 76, 3748-3755. doi: 10.1128/jvi.76.8.3748-3755. 2002

Shmueli, E., Or, R., Shapira, M. Y., Resnick, I. B., Caplan, O., BdolahAbram, T., et al. (2014). High rate of cytomegalovirus drug resistance among patients receiving preemptive antiviral treatment after haploidentical 
stem cell transplantation. J. Infect. Dis. 209, 557-561. doi: 10.1093/infdis/ jit475 doi: 10.1093/infdis/jit475

Shnayder, M., Nachshon, A., Krishna, B., Poole, E., Boshkov, A., Binyamin, A., et al. (2018). Defining the transcriptional landscape during cytomegalovirus latency with single-cell RNA sequencing. mBio 9:e00013-18. doi: 10.1128/mBio. 00013-18

Sinzger, C., Digel, M., and Jahn, G. (2008). Cytomegalovirus cell tropism. Curr. Top. Microbiol. Immunol. 325, 63-83. doi: 10.1007/978-3-540-77349-8_4

Slade, M., Goldsmith, S., Romee, R., DiPersio, J. F., Dubberke, E. R., Westervelt, P., et al. (2017). Epidemiology of infections following haploidentical peripheral blood hematopoietic cell transplantation. Transpl. Infect. Dis. 19:e12629.

Slobedman, B., and Mocarski, E. S. (1999). Quantitative analysis of latent human cytomegalovirus. J. Virol. 73, 4806-4812.

Smirnov, S. V., Harbacheuski, R., Lewis-Antes, A., Zhu, H., Rameshwar, P., and Kotenko, S. V. (2007). Bone-marrow-derived mesenchymal stem cells as a target for cytomegalovirus infection: implications for hematopoiesis, self-renewal and differentiation potential. Virology 360, 6-16. doi: 10.1016/j.virol.2006. 09.017

Soderberg-Naucler, C., Fish, K. N., and Nelson, J. A. (1997). Reactivation of latent human cytomegalovirus by allogeneic stimulation of blood cells from healthy donors. Cell 91, 119-126. doi: 10.1016/s0092-8674(01)80014-3

Söderberg-Nauclér, C., Streblow, D. N., Fish, K. N., Allan-Yorke, J., Smith, P. P., and Nelson, J. A. (2001). Reactivation of latent human cytomegalovirus in $\mathrm{CD} 14(+)$ monocytes is differentiation dependent. J. Virol. 75, 7543-7554. doi: 10.1128/jvi.75.16.7543-7554.2001

Soland, M. A., Keyes, L. R., Bayne, R., Moon, J., Porada, C. D., St Jeor, S., et al. (2014). Perivascular stromal cells as a potential reservoir of human cytomegalovirus. Am. J. Transplant. 14, 820-830. doi: 10.1111/ajt.12642

Suessmuth, Y., Mukherjee, R., Watkins, B., Koura, D. T., Finstermeier, K., Desmarais, C., et al. (2015). CMV reactivation drives posttransplant T-cell reconstitution and results in defects in the underlying TCRbeta repertoire. Blood 125, 3835-3850. doi: 10.1182/blood-2015-03-631853

Sylwester, A. W., Mitchell, B. L., Edgar, J. B., Taormina, C., Pelte, C., Ruchti, F., et al. (2005). Broadly targeted human cytomegalovirus-specific CD4+ and CD8 $+\mathrm{T}$ cells dominate the memory compartments of exposed subjects. J. Exp. Med. 202, 673-685. doi: 10.1084/jem.20050882

Taichman, R. S., Nassiri, M. R., Reilly, M. J., Ptak, R. G., Emerson, S. G., and Drach, J. C. (1997). Infection and replication of human cytomegalovirus in bone marrow stromal cells: effects on the production of IL-6, MIP-1alpha, and TGF-beta1. Bone Marrow Transplant. 19, 471-480. doi: 10.1038/sj.bmt. 1700685

Takenaka, K., Nishida, T., Asano-Mori, Y., Oshima, K., Ohashi, K., Mori, T., et al. (2015). Cytomegalovirus reactivation after allogeneic hematopoietic stem cell transplantation is associated with a reduced risk of relapse in patients with acute myeloid leukemia who survived to day 100 after transplantation: the Japan society for hematopoietic cell transplantation transplantation-related complication working group. Biol. Blood Marrow Transplant. 21, 2008-2016. doi: 10.1016/j.bbmt.2015.07.019

Tan, S. K., Waggoner, J. J., and Pinsky, B. A. (2015). Cytomegalovirus load at treatment initiation is predictive of time to resolution of viremia and duration of therapy in hematopoietic cell transplant recipients. J. Clin. Virol. 69, 179-183. doi: $10.1016 /$ j.jcv.2015.06.006

Taylor-Wiedeman, J., Sissons, J. G., Borysiewicz, L. K., and Sinclair, J. H. (1991). Monocytes are a major site of persistence of human cytomegalovirus in peripheral blood mononuclear cells. J. Gen. Virol. 72(Pt 9), 2059-2064. doi: 10.1099/0022-1317-72-9-2059

Taylor-Wiedeman, J., Sissons, P., and Sinclair, J. (1994). Induction of endogenous human cytomegalovirus gene expression after differentiation of monocytes from healthy carriers. J. Virol. 68, 1597-1604.

Teira, P., Battiwalla, M., Ramanathan, M., Barrett, A. J., Ahn, K. W., Chen, M., et al. (2016). Early cytomegalovirus reactivation remains associated with increased transplant-related mortality in the current era: a CIBMTR analysis. Blood 127, 2427-2438. doi: 10.1182/blood-2015-11-679639

Tey, S. K., Davenport, M. P., Hill, G. R., Kennedy, G. A., Durrant, S. T., Khanna, R., et al. (2014). Post transplant CMV-specific T-cell immune reconstitution in the absence of global T-cell immunity is associated with a high risk of subsequent virus reactivation. Bone Marrow Transplant. 50, 315-316. doi: 10.1038/bmt. 2014.265
Tey, S. K., Kennedy, G. A., Cromer, D., Davenport, M. P., Walker, S., Jones, L. I., et al. (2013). Clinical assessment of anti-viral CD8 $+\mathrm{T}$ cell immune monitoring using QuantiFERON-CMV(R) assay to identify high risk allogeneic hematopoietic stem cell transplant patients with CMV infection complications. PLoS One 8:e74744. doi: 10.1371/journal.pone.0074744

Tong, J., Sun, Z., Liu, H., Geng, L., Zheng, C., Tang, B., et al. (2013). Risk factors of CMV infection in patients after umbilical cord blood transplantation: a multicenter study in China. Chin. J. Cancer Res. 25, 695-703. doi: 10.3978/j. issn.1000-9604.2013.11.08

Tormo, N., Solano, C., Benet, I., Clari, M. A., Nieto, J., de la Camara, R., et al. (2010). Lack of prompt expansion of cytomegalovirus pp65 and IE-1specific IFNgamma CD8+ and CD4+ T cells is associated with rising levels of pp65 antigenemia and DNAemia during pre-emptive therapy in allogeneic hematopoietic stem cell transplant recipients. Bone Marrow Transplant. 45, 543-549. doi: 10.1038/bmt.2009.172

Tormo, N., Solano, C., Benet, I., Nieto, J., de la Camara, R., Lopez, J., et al. (2011). Reconstitution of CMV pp65 and IE-1-specific IFN-gamma CD8(+) and CD4(+) T-cell responses affording protection from CMV DNAemia following allogeneic hematopoietic SCT. Bone Marrow Transplant. 46, 1437-1443. doi: 10.1038/bmt.2010.330

Valadkhani, B., Kargar, M., Ashouri, A., Hadjibabaie, M., Gholami, K., and Ghavamzadeh, A. (2016). The risk factors for cytomegalovirus reactivation following stem cell transplantation. J. Res. Pharm. Pract. 5, 63-69. doi: 10.4103/ 2279-042X.176554

Varanasi, P. R., Ogonek, J., Luther, S., Dammann, E., Stadler, M., Ganser, A., et al. (2019). Cytomegalovirus-specific CD8 + T-cells are associated with a reduced incidence of early relapse after allogeneic stem cell transplantation. PLoS One 14:e0213739. doi: 10.1371/journal.pone.0213739

Vinuesa, V., Bracho, M. A., Albert, E., Solano, C., Torres-Puente, M., Gimenez, E., et al. (2017). The impact of virus population diversity on the dynamics of cytomegalovirus DNAemia in allogeneic stem cell transplant recipients. J. Gen. Virol. 98, 2530-2542. doi: 10.1099/jgv.0.000916

Wagner, J. E., Thompson, J. S., Carter, S. L., Kernan, N. A., and Unrelated Donor Marrow Transplantation Trial. (2005). Effect of graft-versus-host disease prophylaxis on 3-year disease-free survival in recipients of unrelated donor bone marrow (T-cell Depletion Trial): a multi-centre, randomised phase II-III trial. Lancet 366, 733-741. doi: 10.1016/s0140-6736(05)66996-6

Walker, C. M., van Burik, J. A., De For, T. E., and Weisdorf, D. J. (2007). Cytomegalovirus infection after allogeneic transplantation: comparison of cord blood with peripheral blood and marrow graft sources. Biol. Blood Marrow Transplant. 13, 1106-1115. doi: 10.1016/j.bbmt.2007.06.006

Walter, E. A., Greenberg, P. D., Gilbert, M. J., Finch, R. J., Watanabe, K. S., Thomas, E. D., et al. (1995). Reconstitution of cellular immunity against cytomegalovirus in recipients of allogeneic bone marrow by transfer of T-cell clones from the donor. N. Engl. J. Med. 333, 1038-1044. doi: 10.1056/nejm199510193331603

Webb, B. J., Harrington, R., Schwartz, J., Kammerer, J., Spalding, J., Lee, E., et al. (2018). The clinical and economic impact of cytomegalovirus infection in recipients of hematopoietic stem cell transplantation. Transpl. Infect. Dis. 20:e12961. doi: 10.1111/tid.12961

Weinberg, K., Blazar, B. R., Wagner, J. E., Agura, E., Hill, B. J., Smogorzewska, M., et al. (2001). Factors affecting thymic function after allogeneic hematopoietic stem cell transplantation. Blood 97, 1458-1466. doi: 10.1182/blood.v97.5.1458

Widmann, T., Sester, U., Gartner, B. C., Schubert, J., Pfreundschuh, M., Kohler, H., et al. (2008). Levels of CMV specific CD4 T cells are dynamic and correlate with CMV viremia after allogeneic stem cell transplantation. PLoS One 3:e3634. doi: 10.1371/journal.pone.0003634

Wildum, S., Zimmermann, H., and Lischka, P. (2015). In vitro drug combination studies of Letermovir (AIC246, MK-8228) with approved anti-human cytomegalovirus (HCMV) and anti-HIV compounds in inhibition of HCMV and HIV replication. Antimicrob. Agents Chemother. 59, 3140-3148. doi: 10. 1128/AAC.00114- 15

Wills, M. R., Poole, E., Lau, B., Krishna, B., and Sinclair, J. H. (2015). The immunology of human cytomegalovirus latency: could latent infection be cleared by novel immunotherapeutic strategies? Cell. Mol. Immunol. 12, 128138. doi: $10.1038 / \mathrm{cmi} .2014 .75$

Winston, D. J., Huang, E. S., Miller, M. J., Lin, C. H., Ho, W. G., Gale, R. P., et al. (1985). Molecular epidemiology of cytomegalovirus infections associated with bone marrow transplantation. Ann. Intern. Med. 102, 16-20. 
Withers, B., Blyth, E., Clancy, L. E., Yong, A., Fraser, C., Burgess, J., et al. (2017). Long-term control of recurrent or refractory viral infections after allogeneic HSCT with third-party virus-specific T cells. Blood Adv. 1, 2193-2205. doi: 10.1182/bloodadvances.2017010223

Yanada, M., Yamamoto, K., Emi, N., Naoe, T., Suzuki, R., Taji, H., et al. (2003). Cytomegalovirus antigenemia and outcome of patients treated with pre-emptive ganciclovir: retrospective analysis of 241 consecutive patients undergoing allogeneic hematopoietic stem cell transplantation. Bone Marrow Transplant. 32, 801-807. doi: 10.1038/sj.bmt.1704232

Yong, M. K., Ananda-Rajah, M., Cameron, P. U., Morrissey, C. O., Spencer, A., Ritchie, D., et al. (2017a). Cytomegalovirus reactivation is associated with increased risk of late-onset invasive fungal disease after allogeneic hematopoietic stem cell transplantation: a multicenter study in the current era of viral load monitoring. Biol. Blood Marrow Transplant. 23, 1961-1967. doi: 10.1016/j.bbmt.2017.07.025

Yong, M. K., Cameron, P. U., Slavin, M., Morrissey, C. O., Bergin, K., Spencer, A., et al. (2017b). Identifying cytomegalovirus complications using the quantiferon-CMV assay after allogeneic hematopoietic stem cell transplantation. J. Infect. Dis. 215, 1684-1694. doi: 10.1093/infdis/jix192

Yoon, H. S., Lee, J. H., Choi, E. S., Seo, J. J., Moon, H. N., Kim, M. N., et al. (2009). Cytomegalovirus infection in children who underwent hematopoietic stem cell transplantation at a single center: a retrospective study of the risk factors. Pediatr. Transplant. 13, 898-905. doi: 10.1111/j.1399-3046.2008.01084.x

Young, V. P., Mariano, M. C., Tu, C. C., Allaire, K. M., Avdic, S., Slobedman, B., et al. (2017). Modulation of the host environment by human cytomegalovirus with viral interleukin 10 in peripheral blood. J. Infect. Dis. 215, 874-882. doi: 10.1093/infdis/jix043

Zaia, J. A., Gallez-Hawkins, G. M., Tegtmeier, B. R., ter Veer, A., Li, X., Niland, J. C., et al. (1997). Late cytomegalovirus disease in marrow transplantation is predicted by virus load in plasma. J. Infect. Dis. 176, 782-785. doi: 10.1086/ 517301

Zaia, J. A., Sun, J. Y., Gallez-Hawkins, G. M., Thao, L., Oki, A., Lacey, S. F., et al. (2009). The effect of single and combined activating killer immunoglobulin-like receptor genotypes on cytomegalovirus infection and immunity after hematopoietic cell transplantation. Biol. Blood Marrow Transplant. 15, 315-325. doi: 10.1016/j.bbmt.2008. 11.030

Zawilinska, B., Szostek, S., Kopec, J., Piatkowska-Jakubas, B., and Kosz-Vnenchak, M. (2016). Multiplex real-time PCR to identify a possible reinfection with different strains of human cytomegalovirus in allogeneic hematopoietic stem cell transplant recipients. Acta Biochim. Pol. 63, 161-166. doi: 10.18388/abp. 2015_1162

Zhou, W., Longmate, J., Lacey, S. F., Palmer, J. M., Gallez-Hawkins, G., Thao, L., et al. (2009). Impact of donor CMV status on viral infection and reconstitution of multifunction CMV-specific T cells in CMV-positive transplant recipients. Blood 113, 6465-6476. doi: 10.1182/blood-2009-02-203307

Zhu, D., Pan, C., Sheng, J., Liang, H., Bian, Z., Liu, Y., et al. (2018). Human cytomegalovirus reprogrammes haematopoietic progenitor cells into immunosuppressive monocytes to achieve latency. Nat. Microbiol. 3, 503-513. doi: 10.1038/s41564-018-0131-9

Zuhair, M., Smit, G. S. A., Wallis, G., Jabbar, F., Smith, C., Devleesschauwer, B., et al. (2019). Estimation of the worldwide seroprevalence of cytomegalovirus: a systematic review and meta-analysis. Rev. Med. Virol. 29:e2034. doi: 10.1002/ rmv.2034

Conflict of Interest Statement: The authors declare that the research was conducted in the absence of any commercial or financial relationships that could be construed as a potential conflict of interest.

Copyright (c) 2019 Stern, Withers, Avdic, Gottlieb, Abendroth, Blyth and Slobedman. This is an open-access article distributed under the terms of the Creative Commons Attribution License (CC BY). The use, distribution or reproduction in other forums is permitted, provided the original author(s) and the copyright owner(s) are credited and that the original publication in this journal is cited, in accordance with accepted academic practice. No use, distribution or reproduction is permitted which does not comply with these terms. 